\title{
SHRIMP U-Pb DATA of THE PALEOPRoterozoic, Região dos Lagos CompleX, Rio de JANEIRO, BRAZIL: IMPLICATIONS TO RIBEIRA BELT EVOLUTION
}

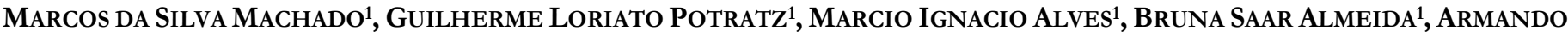 dias Tavares JR ${ }^{3}$, Alexis Rosa Nummer ${ }^{4}$, Camila Cardoso Nogueira ${ }^{2}$, Anderson Costa dos SaNtos ${ }^{2}$ and Mauro CESAR Geraldes ${ }^{2}$}

1 Programa de Posgraduação em Análise de Bacias e Faixas Móveis, Faculdade de Geologia, Universidade do Estado do Rio de Janeiro. Av. São Francisco Xavier, 524, Maracanã. 20550-013 Rio de Janeiro, RJ, Brazil. pardal.uerj@gmail.com, geo.loriato@gmail.com, inacio.marcio@hotmail.com, brunasaar@yahoo.com.br

2 Departamento de Mineralogia e Petrologia Ígnea, Faculdade de Geologia, Universidade do Estado do Rio de Janeiro. Av. São Francisco Xavier, 524, Sala 4024 Maracanã. 20550-013 Rio de Janeiro, RJ, Brazil. geraldes@uerj.br, milaccn@gmail.com, andcostasantos@gmail.com

3 Instituto de Física Armando Dias Tavares, Universidade do Estado do Rio de Janeiro. Av. São Francisco Xavier, 524, Sala 3107 Maracanã. 20550-013 Rio de Janeiro, RJ, Brazil. tavares.armandodias@gmail.com

4 Instituto de Geociências, Universidade Federal Rural Rio de Janeiro. BR-465, Km 7 Seropédica-Rio de Janeiro, Brazil. nummer@ufrrj.br

*Corresponding author, geraldes@uerj.br

Received on 8 December 2017

Received in revised form on 20 January 2018

Accepted on 30 January 2018

Editor: Maria Virginia Alves Martins, Universidade do Estado do Rio de Janeiro, Brazil

\section{Abstract}

The studied region is located in the Rio de Janeiro State (SE, Brazil) and is part of the Ribeira Belt in the central portion of the Mantiqueira Province. The rocks of this region were included in the Brasiliano/Pan-African Orogeny, from Neoproterozoic to the early Paleozoic. The basement is comprised of Paleoproterozoic rocks, sedimentary and volcano-sedimentary rocks from Mesoproterozoic and Neoproterozoic and intrusive granitic rocks from the Neoproterozoic. These rocks are interpreted as associations of magmatic arcs, sedimentary sequences of passive margins and tardi-kinematic granites, respectively. The study area is located in Cabo Frio Terrane, where the basement is represented by the Região dos Lagos Complex.

The Região dos Lagos Complex can be divided into: granitic rocks (biotite-orthoclase-plagioclase gneiss) and tonalitic rocks (biotite-microcline-plagioclase gneiss). The main aims of the SHRIMP U-Pb zircon studies in the Região dos Lagos
Citation:

SCREENED BY iThenticate

Machado, M.S., Potratz, G.L., Alves, M.I., Almeida, B.S., Armando Dias Tavares Jr, A.D., Nummer, A.R., Nogueira, C.C., Santos, A.C., Geraldes, M.C., 2017. SHRIMP U-Pb data of the Paleoproterozoic, Região dos Lagos Complex, Rio de Janeiro, Brazil: Implications to Ribeira Belt evolution. Journal of Sedimentary Environments, 2 (4): 301-318.
Complex are identify the crystallization ages of this complex and to define the magmatic events in the Ribeira Belt. The obtained U-Pb ages are: sample CRL-04, $1960 \pm 19 \mathrm{Ma}$; sample CRL-05, $1986 \pm 24 \mathrm{Ma}$; sample CRL-06, $1985 \pm 34$ $\mathrm{Ma}$; sample CRL-07, $1942 \pm 16 \mathrm{Ma}$; sample CRL-08, $1970 \pm$ $17 \mathrm{Ma}$ and sample CRL-09, $1989 \pm 22 \mathrm{Ma}$.

These results suggest crystallization ages ranging from 1989 Ma to 1942 Ma for the Região dos Lagos complex, and this unit is therefore interpreted as being generated during an important magmatic event related to the Ribeira Belt formed previously to the Gondwana amalgamation and is probably related to the Congo Craton basement.

Keywords: Neoproterozoic Brasiliano - Pan African Cycle. SHRIMP U-Pb. Paleoproterozoic. Sedimentary Rocks. Volcano-Sedimentary Rocks. Ribeira Belt. 


\section{Introduction}

The U-Pb systematic in zircons is one of the most important geochronological tools available in Geology, especially regarding older and metamorphic Precambrian Terranes. In Brazil, most of the territory is composed by a network of Neoproterozoic Belts. Among them, Ribeira Belt is comprised of magmatic and sedimentary rocks reworked during the Neoproterozoic (Fonseca, 1998; Duarte et al., 2000; Heilbron and Machado, 2003) including Paleoproterozoic cratons (São Francisco and Congo) amalgamated during the Gondwana Supercontinent building between the Neoproterozoic Era and the Cambrian Period (Fig. 1). Most of the Belts, at the Brazilian side, are strongly eroded and are made up by high-grade metamorphic terranes.

The study area is part of the Mantiqueira Province, with lithologic and structural complexity affected by the Brasiliano orogenic cycle during the Neoproterozoic (Rosier, 1957, 1965; Leonardos and Fyfe, 1974; Machado et al., 1996; Schmitt, 2001). In general, the mapped rocks include diverse lithotypes grouped in granitoid associations with diverse composition, fabric and structures. According to the previous works and the present study, the following units were proposed: Região dos Lagos, São Fidélis, Búzios, Italva, Rio Negro, Trajano de Moares, Imbé, Desengano, Cordeiro, Serra dos Órgãos, Sana, Serra do Mar mafic dyke swarms, alkaline dykes and recent sediments (Reis et al., 1980; Reis, 1995; Schmitt et al., 2008; 2012a; Almeida et al., 2009; Geraldes et al., 2009).

Tectonically, the rock association may be grouped in three terranes comprised of the Occidental, Oriental and Cabo Frio (Heilbron et al., 1995; Fig. 2). The Oriental terrene represents the major part of the study area where the Rio Negro Complex, Trajano de Moraes Complex, Imbé and Desengano magmatic rocks are observed. Within this area, the São Fidelis Complex is the only supra crustal observed unit. The Occidental terrane is comprised of a small zone in the north of the study area represented by the metasedimentary rocks of the Italva Group. In Cabo Frio Terrane, the Região dos Lagos Complex is the oldest observed unit formed by Paleoproterozoic magmatic rocks covered by the Búzios Platformal metamorphosed sedimentary rocks (Machado and Demange, 1990; Heilbron and Machado, 2003; Heilbron et al., 1974; 1995). Jurassic basic dyke swarms, alkaline rocks and recent sediments occur widespread.

The geologic evolution started with the Paleoproterozoic juvenile Região dos Lagos Complex rocks formed in a magmatic arc and with the deposition of sedimentary covers comprising the São Fidelis, Búzios and Italva units. A new magmatic arc was developed during the Neoproterozoic Era and generated the rocks from the Rio Negro Complex and Trajano de Moraes Complex rocks (Tupinambá et al., 2007). Collisional processes were responsible for the formation of younger granitic rocks represented by the Cordeiro (S-type granites), Serra dos Órgãos and Sana (probably I-type granites) although they still have unknown age and tectonic settings (Trouw et al., 2000; Silva et al., 2002; Viana, 2008). The granitic suites, observed in the study area, are important for the characterization of the Neoproterozoic collisional features under debate in the scientific community.

The mineral resource potential of the focused area is comprised of sands, clay, marble, dimension stones and pegmatite and mineral water still under explored potential in the region.

This work presents new SHRIMP U-Pb data for the Paleoprototezoic orthogneisses of the Cabo Frio Terrane of Ribeira Belt and discusses the implication of this Paleoproterozoic fragment during the evolution of Ribeira Belt in the context of West Gondwana amalgamation using crystallization ages obtained in Curtin University in Perth SHRIMP facilities.

This study aims to constrain the U-Pb ages for the basement rocks of the Cabo Frio Terrane and to compare these with the crystallization ages published for the basement of the Juiz de Fora Complex and Congo Craton. The authors also compare the data with the Costeiro Domain sedimentary cover different ages obtained for the basement rocks in the Cabo Frio Terrane and in the Costeiro Domain rise an important question about the origin of sedimentary cover put side-by-side by tectonic boundary and about the Ribeira Belt crustal evolution.

\section{Geology of the Cabo Frio Terrane}

The Região dos Lagos Complex area is part of the Cabo Frio (tectonic) Terrane (Fig. 3) which is inserted in the Ribeira Belt. This terrane was amalgamated during the Cambrian and Ordovician, characterizing Búzios Orogeny (Schmitt et al., 2012a), the last event in theGondwana collage.

The Ribeira Belt belongs to the Mantiqueira Province, developed during the Brazilian Neoproterozoic Orogeny that resulted in the formation of the Paleocontinent Gondwana (Fig. 1). This Belt consists of a complex system of folds and thrusts, with an NE-SW extension of about $1400 \mathrm{Km}$, along the southeastern coast of Brazil.

The Ribeira Belt is bordered to the South by the Craton Luis Alves, to the North by the Araçuai Belt and to the Northwest by the Interference Zone between the Ribeira and Brasília Belts (Heilbron, 2004).

Heilbron (2004) divided the Ribeira Belt in the following tectono-stratigraphic domains: Occidental Terrane, Costeiro Terrane and Cabo Frio Terrane, Eastern Terrane, with the first three being amalgamated ca. $580 \mathrm{Ma}$, while the Cabo Frio Terrane was only put together to the others in ca. $520 \mathrm{Ma}$ (Fig. 1). 
The Cabo Frio Tectonic Domain (Schmitt et al., 2008) or Cabo Frio Terrane (Heilbron, 2004) is limited to NW by a shear zone with NE-SW direction which separates the Cabo Frio Terrane from the Costeiro one and to SE is covered by the Atlantic Ocean. In Cabo Frio Tectonic Terrane, two main lithological groups are found: basement and supracrustal ones, differentiated by their genesis and ages (Delhal et al., 1969; Zimbres et al., 1990; Fonseca, 1994a; Viana et al., 2008). The first one comprises the lithological group of the basement with Paleoproterozoic crystallization age, dated by $\mathrm{U}-\mathrm{Pb}$ in zircon ranging from 2.03 to $1.96 \mathrm{Ga}$; and Cambrian metamorphism age, dated by U-Pb in zircons of about 517 Ma in syntectonic veins. Schmitt et al. (2008) divides the basement into two units, the felsic orthogneiss named Region dos Lagos and Forte de São Mateus.

The protoliths for the orthogneisses include quartzdiorites, tonalites and granitoids with microdioritic enclaves, while the ortho-amphibolites have their protoliths basic plutonic and volcanic igneous rocks that are differentiated into two groups: clinopyroxene banded and homogeneous ortho-amphibolite, the latter interpreted as old dykes.

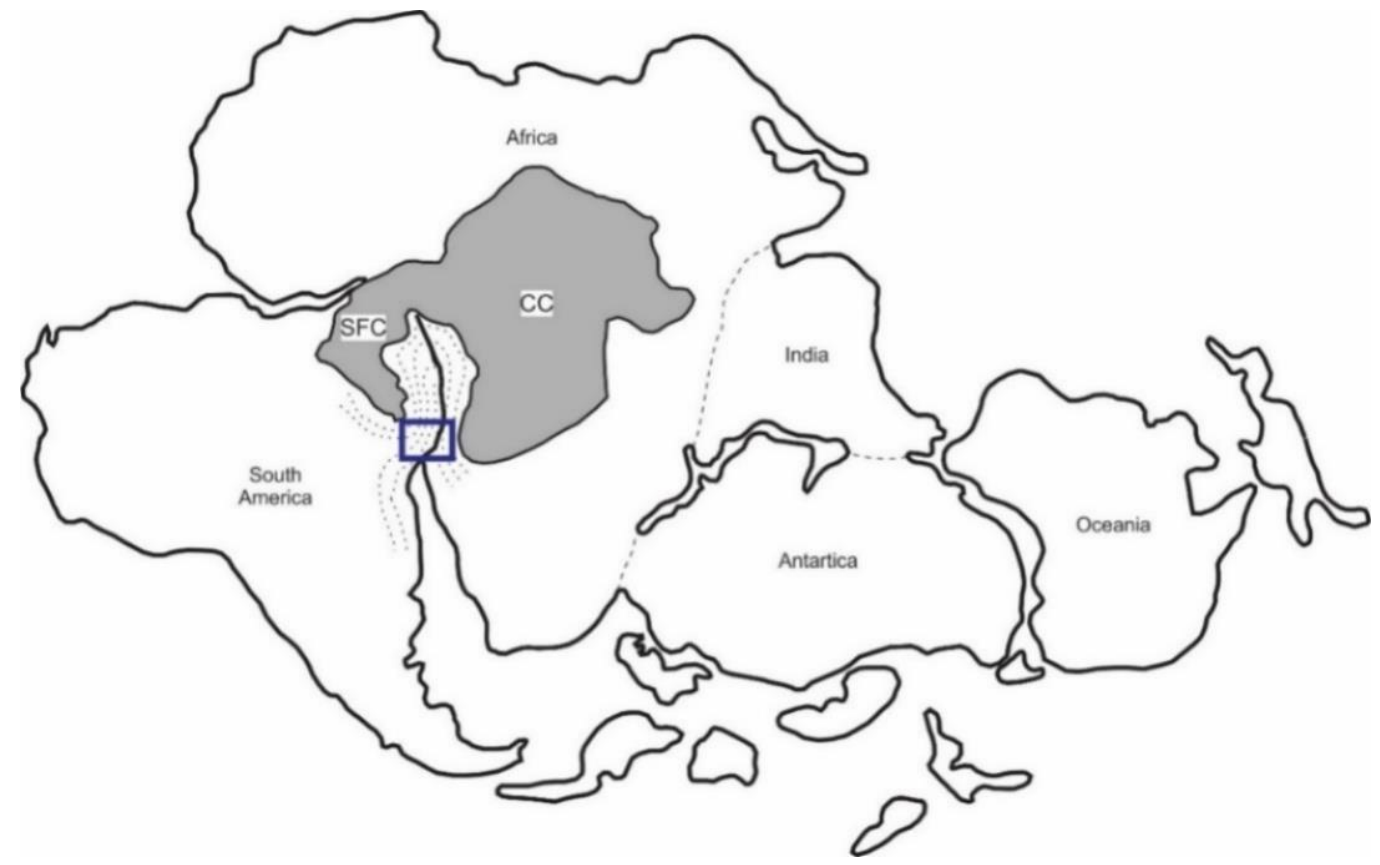

Fig. 1. Paleogeographic reconstruction of Gondwana Supercontinent. Legend: CC - Congo Craton; SFC - São Francisco Craton. Blue rectangle representsthe study area.

The second lithological group of the Cabo Frio Tectonic Terrane constitutes a younger supracrustal sequence, comprised of metasedimentary rocks of the Búzios-Palmital Basin, with a maximum age of $590 \mathrm{Ma}$ (Schmitt et al., 2008). This sequence is divided into Búzios Succession and Palmital Succession. The first one consists mainly of aluminous metapelites, however, calc-silicate rocks, amphibolites and subordinate quartz-feldspar rocks also occur, while the second one is composed mainly by paragneisses, also occurring calc-silicate rocks and subordinate metapelites.

After the Brasiliano events, the entire Ribeira Belt was affected by reactivations during the Cretaceous (145-65 Ma), corresponding to the Gondwana breakup and formation of the South Atlantic Ocean (Trompette, 1994; Geraldes et al., 2013). This event is represented by extensive basic magmatism, through the intrusion of basaltic dykes and the beginning of the blocks uplift during the Tertiary, followed by faults, fractures and block movements giving rise to the sedimentary basins of the continental margin, such as the
Campos and Santos Basins. At the end of the Cretaceous and the beginning of the Tertiary there was a voluminous alkaline bodies intrusion.

\section{Região dos Lagos Complex}

The Região dos Lagos Complex comprises orthogneiss rocks of granitic to tonalitic composition. These rocks present deformation and metamorphism and can be characterized by metagranitoids and subordinated metadiorites, with a wide deformation intensity.

The main evidences that allow classify as ortho-derivative rocks are the mineralogical composition (mainly amphibole and absence of aluminous minerals), intrusive contacts feature between facies belonging to the Região dos Lagos Complex and gradation of the less deformed domains to more deformed ones, indicating that the finely banded gneisses are formed in shear zones. 


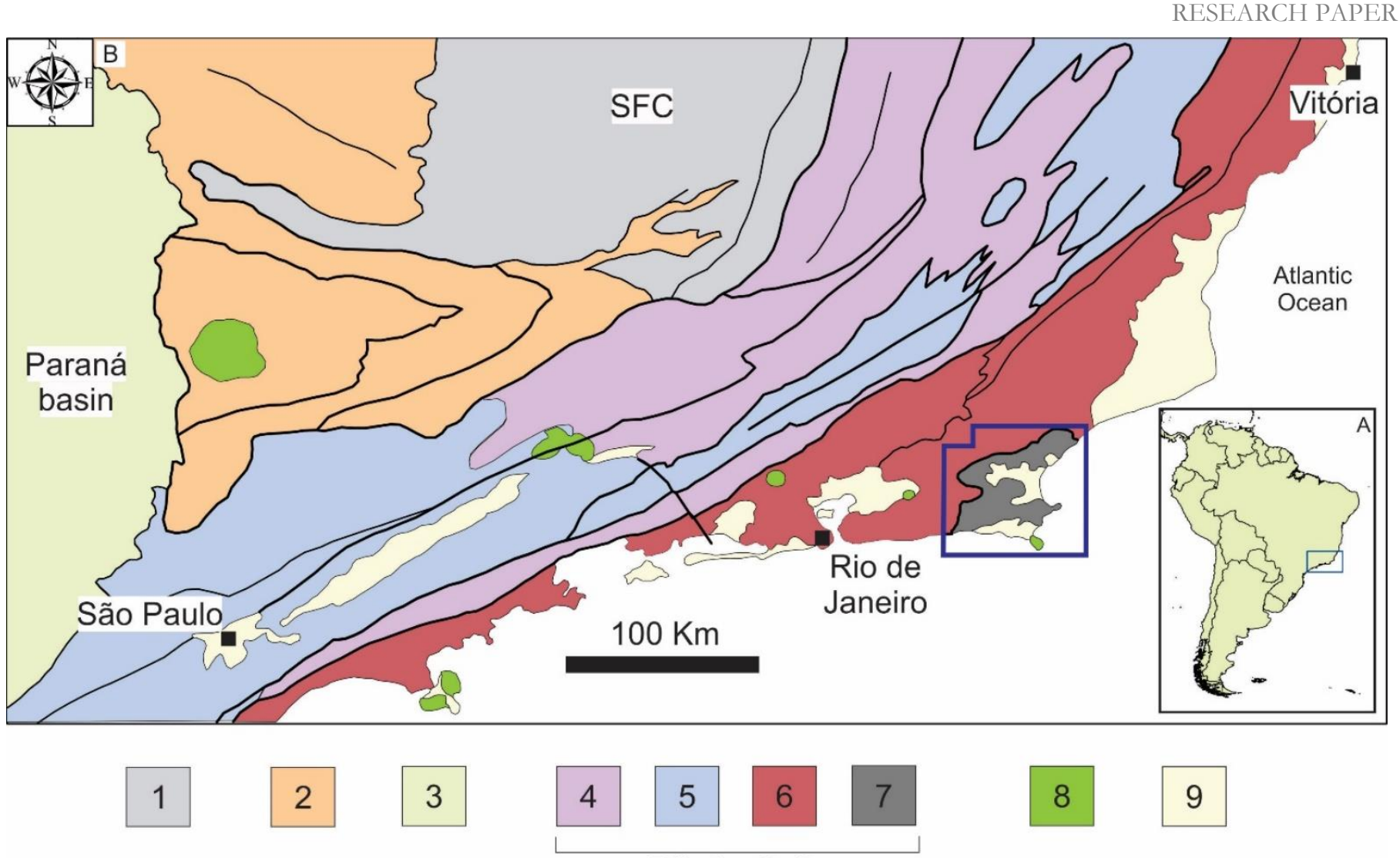

\section{Ribeira Belt}

Fig. 2. Brazil Southeast region focusing in the Central Ribeira Belt with major tectonic units. (1) São Francisco Craton; (2) Brasiliano Mobile Belt; (3) Paraná Basin; (4) Occidental Terrane; (5) Paraíba do Sul Unit; (6) Costeiro Terrane; (7) Região dos Lagos Complex; (8) alkaline intrusions; and (9) recent sediments. The blue rectangle is presented in detail in Figure 3 and corresponds to the study area. Legend: CSF - São Francisco Craton (based on Heilbron et al. (1995).

The main rocks observed in this unit are metaquartzdiorites, metatonalites, microdioritic enclaves and quartzfeldspathic veins. According to Rosier (1957), who identified the Precambrian rocks in the area, the lithotypes probably belong to the magmatic basement. In slightly deformed areas, igneous protoliths are easily identified whereas in very deformed areas, partial fusion and deformation transform this basement into migmatites, whose protoliths are difficult to recognize.

The Região dos Lagos Complex was named by Reis et al. (1980) who investigated the basement in the region. The mapping of lithological units in the Rio de Janeiro State, the Região dos Lagos unit is easily recognizable in the adopted scale (1: 50000) and descriptive character (Reis, 1995). The Região dos Lagos Unit was described as heterogeneous migmatites represented by medium to fine-grained biotite gneisses and hornblende-biotite gneisses with granitic and pegmatitic veins. The igneous protolith for the basement, due to its homogeneity and composition was suggested by several authors (Machado and Demange, 1990; Fonseca, 1994b; Viana, 2008; Schmitt et al., 2008). These authors described the Região dos Lagos as a unit with deformed granitoids yielding a Paleoproterozoic age composed of tonalitic to granodiorite gneisses with subordinated granites.

\section{Material and methods}

Approximately $30 \mathrm{Kg}$ of fresh rock were collected in six sites (Table 1). Each sample was crushed in two different mills and followed mineral separation by panning concentration, using dense liquid (bromoform) and a Frantz magnetic apparatus. Finally, the representative zircon grains were handpicked using binocular microscope with selection of representative zircon grains from all magnetic susceptibility fractions. Selected zircon grains were displayed in an epoxy mount for the cathodoluminescent (CL) imaging in scanning electron microscope (SEM) using a QUANTA 250 (FEI) in order to be prepared for the isotopic analysis according to procedures described in Geraldes (2010). The $\mathrm{U}-\mathrm{Pb}$ isotopic analyses were performed using the Sensitive High-Resolution Ion Microprobe (SHRIMP-II) at Curtin University (Perth, Australia). 


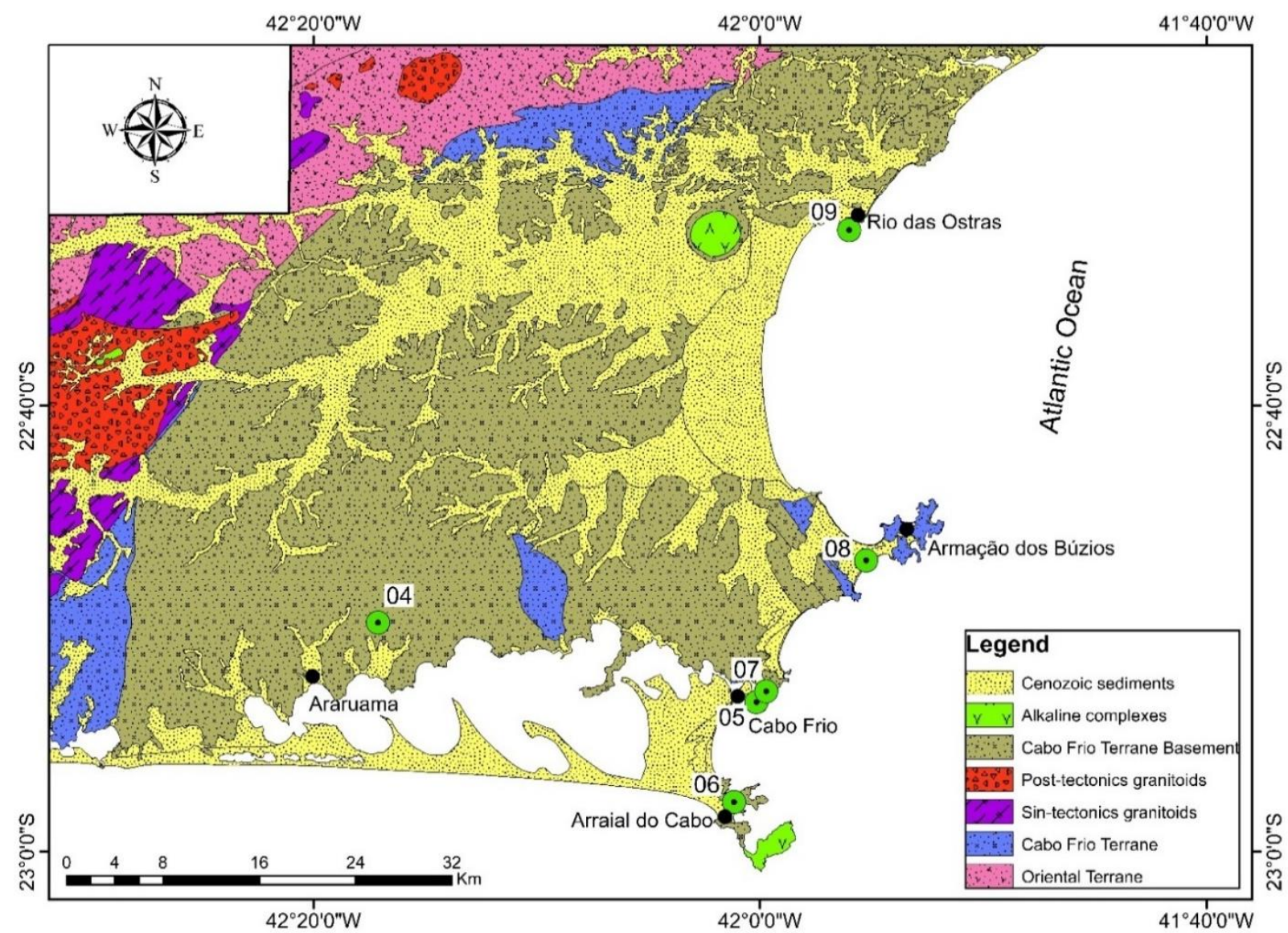

Fig. 3. Cabo Frio Terrane and Ribeira Belt units in the studied region. Location of rock samples are showed in the map (based on Schmitt et al., 2012b).

Data were plotted on concordia diagrams using isoplot 3.00 excel software (Ludwig, 2003). Details of the analytical procedures of zircons using SHRIMP were described by Compston et al. (1992). Interelement fractionation ion emission of zircon was corrected relative to the reference material TEMORA 1 (417 Ma; Black et al., 2003).

The zircons obtained from the collected samples were separated into 6 fractions of magnetic susceptibility by varying the angle of inclination in the Frantz magnetic separator at $5^{\circ}, 3^{\circ}, 1^{\circ}, 0^{\circ},-5^{\circ}$ and not attainable. The uncertainties in ages are cited as $1 \sigma$ and the weighted mean ages are quoted at the $95 \%$ confidence level $(2 \sigma)$. All ages

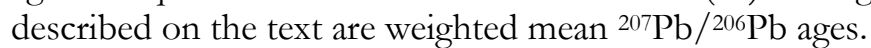

\subsection{Petrography and SHRIMP U-Pb zircon data}

In order to study the orthogneisses of the Região dos Lagos Complex, tonalite and granite outcrops with different textures were selected. In Arraial do Cabo (1 sample), granodioritic samples present large amount of magnetite and strong foliation. Crossing the Via Vagos road, the Região dos Lagos rock outcrops (3 samples) present structural complexity, including migmatitic textures leucogranites and granodiorite-tonalite intercalation, which are folded and cut by pegmatitic rocks with granitic composition.

The four samples collected in Cabo Frio and Búzios cities present granitic to granodioritic composition with gneissic features due to strong foliation and mafic minerals orientation, having local phenocrysts of potassic feldspar. Around Rio das Ostras city (4 samples) the rocks are granite and granodiorite in composition and vary from fine-grained to coarse-grained.

\section{Results}

The location of the six samples of the orthogneisses of the Região dos Lagos Complex selected for geochronological investigation is presented in Figure 3 and the outcrop description of the samples in Figure 4. Figure 5 represents thin section photomicrography of those samples collected in field work. Figure 6 presents cathodoluminescence (CL) images of the analyzed zircon grains. Figure 7 includes the concordia diagram with the plot of the U-Pb isotopic results. 
Table 1. Sampling sites location (Datum WGS-84).

Sample

\begin{tabular}{l|l|l|l}
\multicolumn{1}{c}{ Sample } & \multicolumn{1}{c}{ Region } & \multicolumn{2}{c}{ Location } \\
\hline CRL 04 & Região dos Lagos Road & $22^{\circ} 48^{\prime} 58^{\prime \prime} \mathrm{S}$ & $42^{\circ} 12^{\prime} 10^{\prime \prime} \mathrm{W}$ \\
\hline CRL 05 & Arraial do Cabo & $22^{\circ} 58^{\prime} 04^{\prime \prime} \mathrm{S}$ & $42^{\circ} 01^{\prime} 56^{\prime \prime} \mathrm{W}$ \\
\hline CRL 06 & Forte de São Matheus & $22^{\circ} 52^{\prime} 44^{\prime \prime} \mathrm{S}$ & $41^{\circ} 59^{\prime} 45^{\prime \prime} \mathrm{W}$ \\
\hline CRL 07 & Ostras Beach & $22^{\circ} 52^{\prime} 29^{\prime \prime} \mathrm{S}$ & $41^{\circ} 59^{\prime} 19^{\prime \prime} \mathrm{W}$ \\
\hline CRL 08 & Geriba Beach & $22^{\circ} 46^{\prime} 45^{\prime \prime} \mathrm{S}$ & $41^{\circ} 54^{\prime} 43^{\prime \prime} \mathrm{W}$ \\
\hline CRL 09 & Rio das Ostras coastline & $22^{\circ} 32^{\prime} 09^{\prime \prime} \mathrm{S}$ & $41^{\circ} 56^{\prime} 58^{\prime \prime} \mathrm{W}$ \\
\hline
\end{tabular}

\subsection{Sample CRL-04}

The rock sample CRL-04 was collected in a cut of Lagos road, nearby Iguaba Grande Town (Fig. 3). The outcrop is over 100 meters in length, and comprises magmatic rocks with migmatized portions. The migmatization is observed (Fig. 4A) in a varied and extensive way and covers the whole area. The process starts from the segregation of mobilized quartz-feldspathic, with high prevalence of feldspar (Fig. 5A). The mobilized material forming pegmatites are composed of microcline plagioclase and quartz. There is segregation of irregular quartz pockets followed by migmatization. This mobilized (pegmatite) segregates in thin light bands, of venule structure to striped, little persistent, generally concordant with the foliation. The mobilization may also be irregular, featuring the rock with spots of biotite and/or amphibole masses within the newly formed material.

The collected sample is a meta-granite with a well developed schistosity, cut by magnetite hornblende biotite pegmatitic veins with $10 \mathrm{~cm}$ width. In hand sample, the metagranite is medium to coarse-grained and the mineralogy consists of quartz, microcline, plagioclase, biotite, amphibole and magnetite. Under the microscope the rock presents granolepidoblastic texture defined by mafic layers with biotite amphibole and magnetite. Chlorite and sericite are secondary minerals and replaces amphiboles and feldspar as retrogressive phases.

The zircon grains (Fig. 6A) are morphologically ranging from prismatic to elongated and have a length/width ratio ranging from 1:1 to 1:5. In general, the grains show rounded facies and in rare cases pyramidal endings. The cathodoluminescence (CL) images of these grains show welldefined oscillatory zoning (with layers varying in thickness), a typical growth texture in magmatic processes.

Grains present prismatic and rounded habit, ranging from euhedral to subhedral, with edges ranging from sub-angular to angular. The crystal grains have moderate to low sphericity, having fractured areas. Some grains have welldefined internal zoning and others have an oscillatory zoning. In some cases, a highlighted color is observed. For this sample, 8 spots were performed (Appendix 1), which were discordant and plotted below the concordia curve, generating a population that define a discordia with an upper intercept crystallization age of $1985 \pm 34 \mathrm{Ma}$ interpreted as a crystallization age marking the upper intercept of the concordia curve (analytical data presented in Table 1). The MSWD (mean square weighted deviation) is 21 (Fig. 7A).

\subsection{CRL-05}

The rock sample CRL-05 was collected on the Forte São Mateus beach, in Cabo Frio Town (Fig. 3). An important feature of this complex is the presence of numerous bodies of dykes, sills and bodies of extremely irregular shape, of aplite and pegmatite rocks that randomly inject the host rocks. Such bodies rarely exceed 0.5 meters thick. Sometimes the contact between these bodies and the host rock is well defined, but in other situations the contact is irregular and diffuse.

Rocks with granodioritic composition are macroscopically composed of quartz, plagioclase, K-feldspar and biotite. The rock has a fine texture with a medium yellowish gray color. Microscopically it is composed by quartz, plagioclase, K-feldspar, biotite and rare amphiboles (Fig. 5B), in addition to opaque (magnetite). Chlorite occurs as retrograde metamorphism replacing biotite.

The morphology of the zircon grains of the sample CRL 05 (Fig. 6B) presents a length to width ratio of $1: 1$ to $1: 5$. It is emphasized in the images of $\mathrm{CL}$ whitish edges involving dark gray core. Grains present prismatic and rounded habit, ranging from euhedral to subhedral, with edges ranging from sub-angular to angular.

The crystal grains have moderate to low sphericity, having fractured areas. Some grains have well-defined internal zoning and others have an oscillatory zoning, in some cases with the highlighted color. When the core presents lighter gray color, the oscillatory zoning is observed. The Paleoproterozoic ages of 1986 \pm 24 Ma were measured for the zircon grains of the sample CRL 05 (results are presented in Appendix 1; MSWD = 3.2; Fig. 7B). 

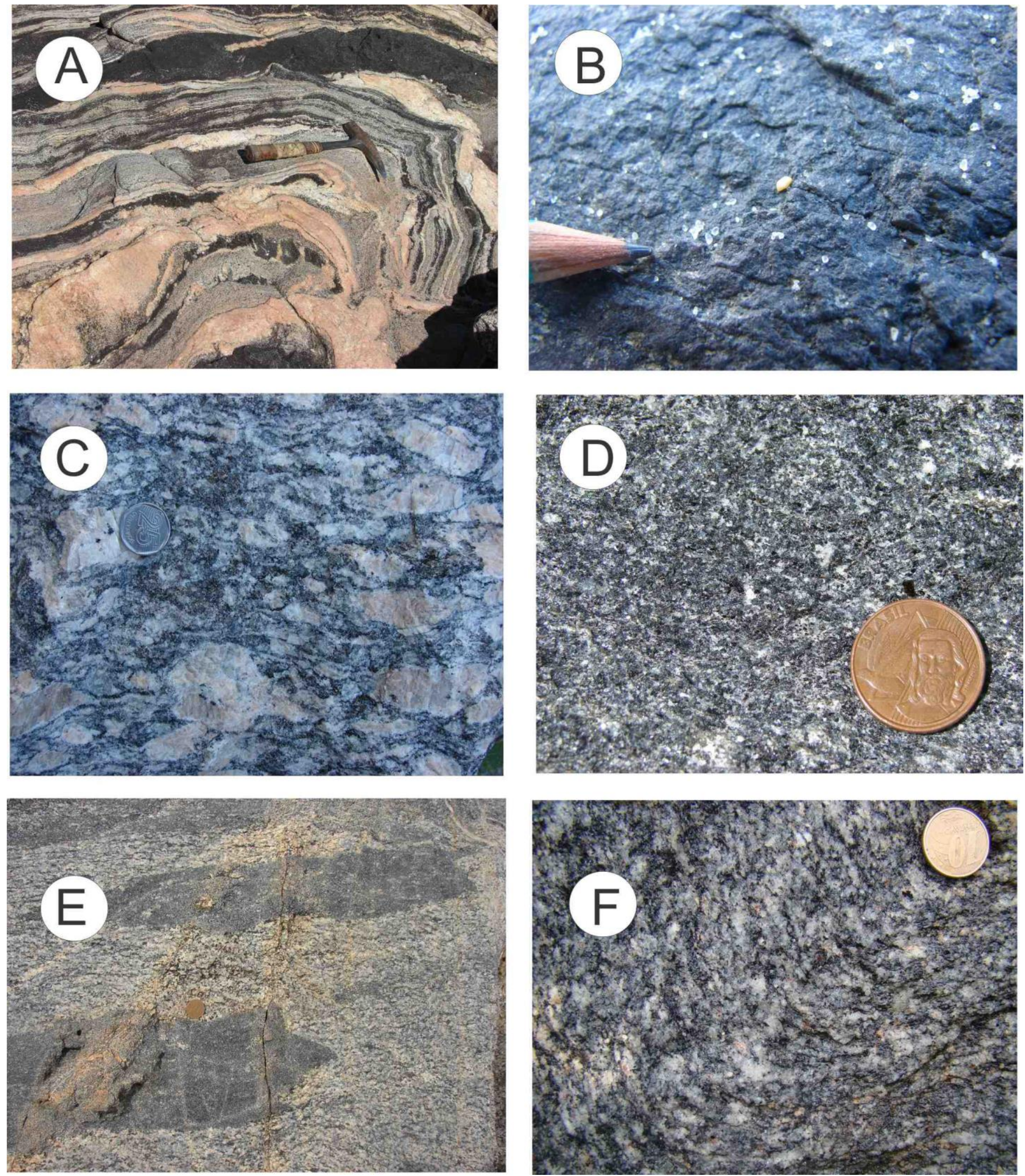

Fig. 4. Samples in outcrop scale showing main features. See text for description. (A) Banded granitic gneiss; (B) tonalitic composition rock; (C) Large K-feldspar phenocrystals in granitic geniss; (D) fine-grained granodioritic rock; (E) maphic xenolites within granodioritic rock with strong orientation; $(\mathrm{F})$ Folded granitic gneiss. 

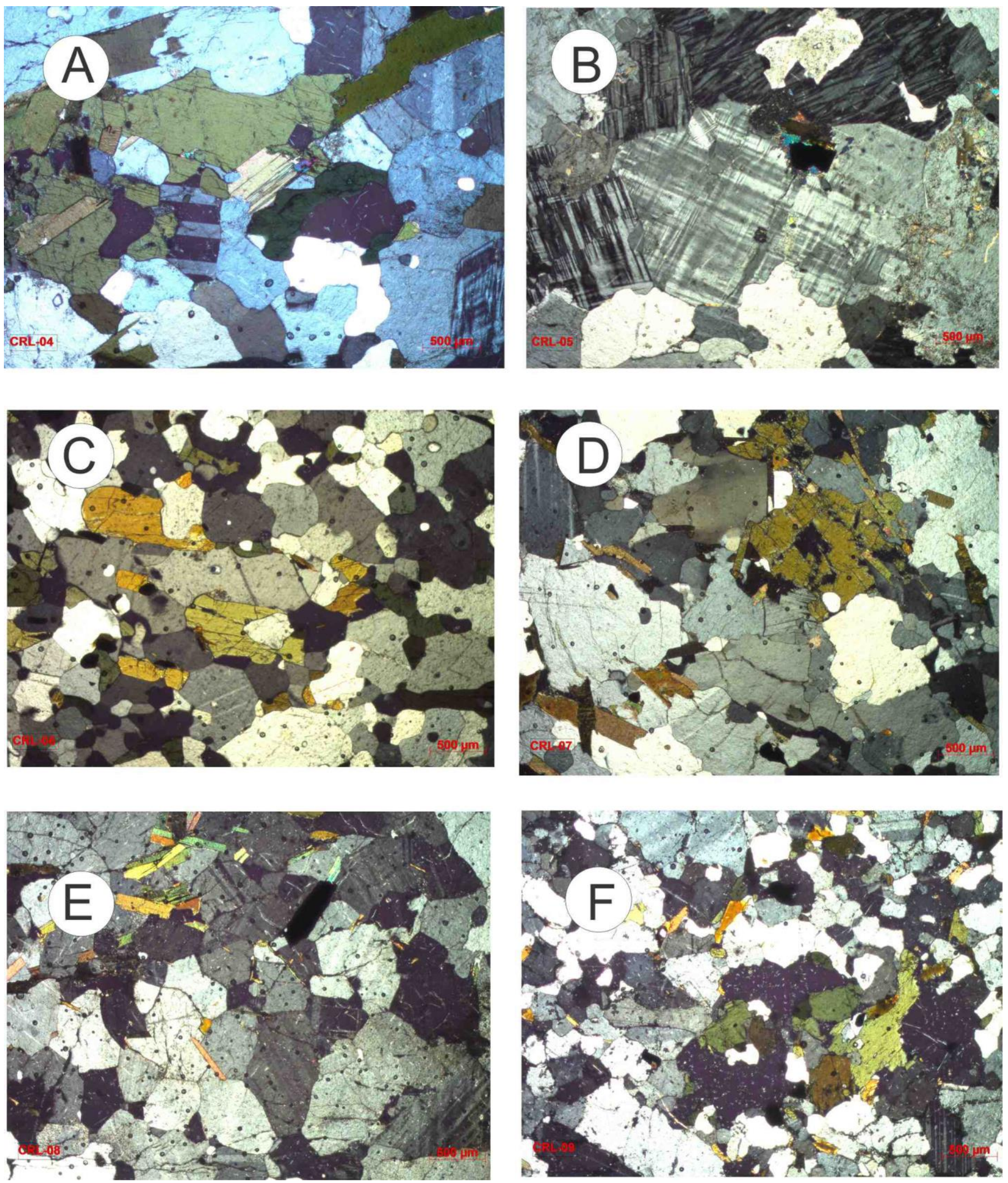

Fig. 5. Tin section imagens of the studied rocks. Descriptions are presented in the text. (A) Tonalite; (B) K-feldspar phenocrystals in granodioritic gneiss; (C) Granodiorite with metamorphic texture; (D) Granite; (E) Felsic rock; (F) Fine-grained metamorphic granitic rock. 


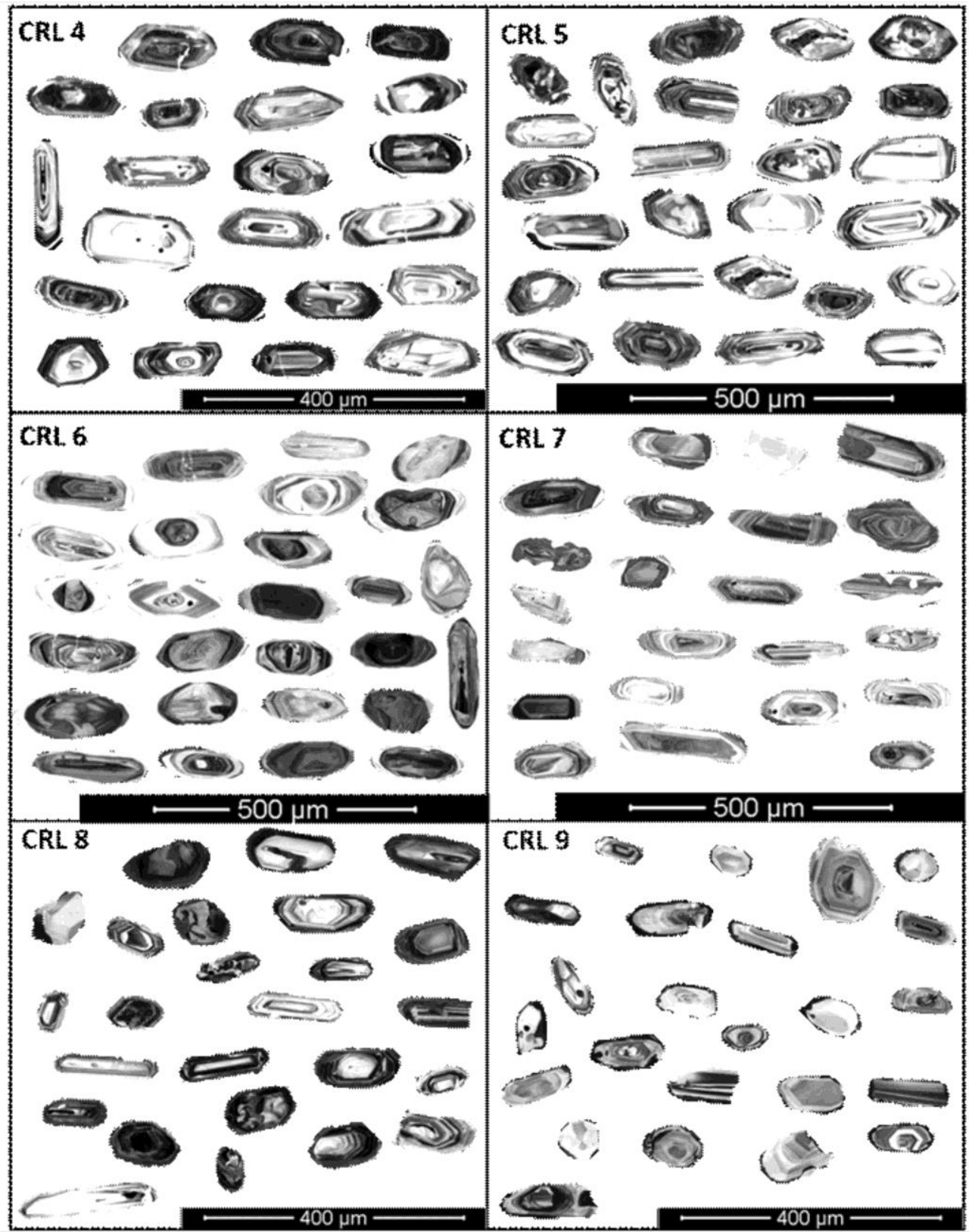

Fig. 6. Cathodoluminescence images of the analyzed zircon grains. The grains present zoning results of magmatic growth, as observed in the cathodoluminescence images. The grains are euhedral, bipyramidal with ratio/width ranging from 4:1 to 2:1.

\subsection{CRL-06}

The rock sample CRL-06 was collected in an outcrop in Arraial do Cabo Town (Fig. 3). The granodioritic rocks (Fig. $4 \mathrm{C})$, under the microscope, present essential mineralogy defined by quartz grains invariably xenomorphic, plagioclase, biotite and hornblende (Fig. 5C). There is an association between mafic minerals, such as biotite, hornblende and opaque minerals. Some hornblende crystals have corroded edges with quartz and plagioclase. Plagioclase is andesine in composition, predominantly polysynthetic twinning according to the law of albite and combination albitepericline. Opaque minerals have irregular shapes. Apatite occurs in well formed crystals and prismatic zircon crystals are rare. Saussurite, chlorite and muscovite are secondary minerals resulting from retro-metamorphism.

Outcrops present migmatitic features and intercalation with deformed decimetric amphibolite bands. Pegmatite rocks with pockets features occur cutting these aforesaid rocks. The sample has granodioritic composition and is slightly foliated with mica (biotite) orientation. Microscopically, it contains quartz, plagioclase and intermediate proportions of $\mathrm{K}$ feldspar. Interstitial grains of magnetite besides amphibole and biotite are present. The granolepidoblastic texture of quartz + feldspar grains indicate recrystallization. 

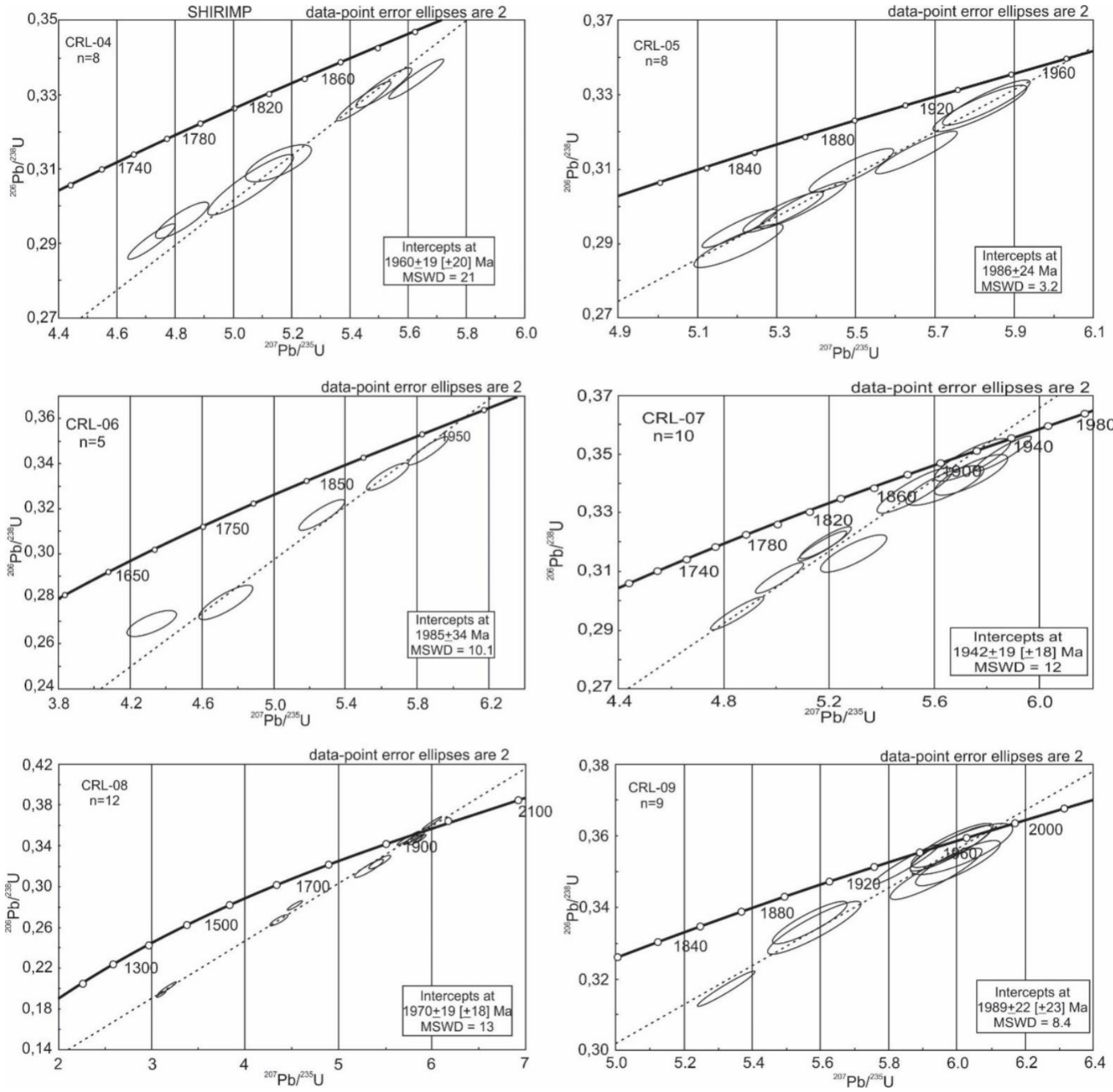

Fig. 7. Concordia diagrams of U-Pb results generated using Isoplot 3.00

For this sample, a total of 8 grains (Fig. 6C) were used, which generated the analytical data presented in Appendix 1. The group of grains present prismatic and granular habit, ranging from euhedral to subhedral, with rounded to subrounded edges. Some grains have a well-defined internal zoning and others an oscillatory zoning. In some cases, the grains have dark color, possibly caused by high $\mathrm{U}$ content and in others, a well-defined nucleus is observed.

Most of the analyses (spots) are concordant, with values ranging from $90 \%$ to $110 \%$. The zircon analyses exhibit
$\mathrm{U} / \mathrm{Th}$ values ranging from 0.5 to 1.5 , which are associated with zircon grains derived from felsic to intermediate magmatic rocks.

The measurements with the best analytical consistency were selected for the construction of the Wetherill concordia diagram and the age calculation. Such calculation takes into account the ${ }^{207} \mathrm{~Pb} / 235 \mathrm{U}$ and ${ }^{206} \mathrm{~Pb} /{ }^{238} \mathrm{U}$ ratios. The age obtained at the Discordia upper intercept of $1985 \pm 34 \mathrm{Ma}$ (MSWD =10.1) is interpreted as the crystallization age of the magmatic orthogneiss protolith (Fig. 7C). 


\subsection{CRL-07}

The rock sample CRL-07 was collected at the Praia das Conchas in Cabo Frio, a famous touristic site (Fig. 3). The rock is, in composition, a medium to fine-grained granite (Fig. 4D), with little foliation.

Microscopically, the rock is composed of quartz, microcline, plagioclase, sericite, biotite and chlorite. That replaces biotite. Sericite occurs growing on microcline and plagioclase. Quartz exhibits locally undulose extinction. Locally diorites and quartz-diorites (occurring as mafic clots) are observed. The hornblende granodiorite (Fig. 5D) presents incipient foliation.

Granites are fine to coarse-grained. The essential mineralogy is given by quartz, microcline, plagioclase, orthoclase, biotite, allanite and opaque minerals. Zircon, titanite and apatite occur as accessory minerals. Saussurite, chlorite and muscovite occur as product of retro metamorphism.

Quartz presents two modes of occurrence. In the first one the crystals are xenoblastic with systematic undolose extinction and are invariably limpid. The second one occurs as rounded inclusion in plagioclase and K-feldspar.

The plagioclase presents andesitic composition $\left(\mathrm{An}_{60^{-}}\right.$ $\left.\mathrm{Ab}_{40}\right)$ and is frequently altered and exhibits pervasive saussuritization. Allanite crystals occurs in rectilinear contact, fracturing grains of felsic minerals such as: microcline, plagioclase, orthoclase and quartz.

The CL images show zircon grains (Fig. 6D) with core and border with the same ages, suggesting growth in one magmatic event. Assembly of zircon mostly with an extended prismatic habit that may become sub-rounded, most grains have a well-delimited internal zoning, with some cases of undefined internal zoning. In cases where the core is light gray, more precise paleoproterozoic ages were obtained, suggesting the preservation of the original isotopic composition. The edges of the zircon grains occur in light gray or dark gray color and do not show very light oscillatory zoning, but tend to have color variation patterns. The concordia obtained using 10 analyzed zircon grains (analytical data presented in Appendix 1) define an upper intercept of $1942 \pm 16 \mathrm{Ma}$ (MSWD =12) that is interpreted as the age of crystallization of the magmatic protolith for these orthogneisses (Fig. 7D).

\subsection{CRL-08}

Sample CRL-08 was collected in Búzios and in Geriba Beach (Fig. 3), at the outcrop below the contact between the basement represented by the Região dos Lagos Complex and supracrustal rocks (paragneiss) of Palmital Formation. These orthogneisses (Fig. 4E) are rocks with weak foliation and sometimes is penetrative. these rocks are fine to mediumgrained and are composed essentially of biotite, quartz, hornblende and plagioclase. (Fig. 5E). The biotite grains are idioblastic with irregular endings. The hornblende grains present substitution at their edges of the tremolite-actinolite minerals. The plagioclase is andesine, with polysynthetic twinning and its grains undergo a process of alteration (saussurite and muscovite) by the plans of its twinning. Titanite often occurs bordering the opaque minerals and apatite grains occur as inclusions in all others mineral phases.

The rock has granitic composition with amphibole-rich portions in granodioritic composition (Fig. 4E). The collected sample has a large proportion of $\mathrm{K}$-feldspar with quartz and little amount of modified plagioclase for sericite. Some biotite grains define the foliation of the rock.

In the sample CRL 08 a total of 12 grains (Fig. 6E) were used, whose analytical data are presented in Appendix 1. This sample is composed of grains with elongated prismatic habit, varying from rounded to subrounded. It is observed a welldefined zoning in some grains and in other cases an unidentified internal zoning and dark nucleus, possibly due to high content of $\mathrm{U}$ and $\mathrm{Th}$. In the construction of the concordia diagram and age calculation $\left({ }^{207} \mathrm{~Pb} /{ }^{235} \mathrm{U}\right.$ vs. $\left.{ }^{206} \mathrm{~Pb} /{ }^{238} \mathrm{U}\right)$, the selected data presented better analytical consistency with concordances ranging from $70 \%$ to $99 \%$ and errors smaller than $1 \%$ resulting in ellipses of small dimensions. The age obtained in the upper intercept of 1970 $\pm 17 \mathrm{Ma}$ (MSWD = 13) is interpreted as the age of crystallization (Fig. 7E).

\subsection{CRL-09}

The rock sample CRL-09 was collected in Rio das Ostras coast line (Fig. 3). The rock (Fig. 4F) has a gray color, has a porphyritic texture and a granite composition marked by the presence of quartz, K-feldspar and plagioclase. K-feldspar and plagioclase crystals have sizes up to $1 \mathrm{~cm}$.

Locally, the hornblende-rich granodiorites are mesocratic, fine to medium-grained and sometimes present an incipient foliation defined by biotite. Its main mineralogy is given by quartz, plagioclase, biotite, microcline and hornblende (Fig. $5 \mathrm{~F})$. The plagioclase grains present diffuse twinning. Opaque minerals are associated with biotite and sometimes have a cubic habit. Titanite, apatite and zircon occur as accessory minerals. Saussurite and chlorite occur as plagioclase and biotite alteration minerals, respectively.

The analytical data of the U-Pb analyses of the sample CRL 08 (zircon grains are presented in Fig. 6F). This sample has grains with prismatic elongated habit, ranging from subrounded to rounded and grains are fractured. Internal structures are not always well identified, with cases where the nuclei are well defined and an oscillatory zoning is observed. The results are given in Appendix 1. They have errors less than $7.5(\%)$ and concordant values ranging from $70 \%$ to $123 \%$. For this sample, 12 spots were performed, which were 
concordant or plotted near the concordia curve, yielding a crystallization age of $1989 \pm 23 \mathrm{Ma}$ marking the upper intercept. The MSWD was 8.4 (Fig. 7F).

\section{Discussion}

The structural evolution of the Ribeira Orogeny is described based on an evolutionary model in a predominantly transpressive tectonics regime. The crustal convergence between the different terrains occurred mainly due to the EW orientation drift, which is recorded in different rocks by the action of ductile shear zones from high to low angle and folds associated to the main deformation phase at the moment of collision (Schmitt et al., 2012b). In the later stages of this collision, an oblique convergence with distributed deformation has developed throughout the entire orogen.

The Região dos Lagos Complex comprises rocks with tonalitic, granodioritic and granitic rock composition, with a varied structural geology, with lenses and enclaves of dioritic and amphibolitic rocks. Among the orthogneisses, two lithotypes are more common: hornblende biotite gneisses with granodioritic to tonalitic composition, containing dioritic and tonalitic enclaves, and biotite gneisses foliated locally porphyritic. These two lithotypes occur sometimes intercalated, but in some regions, they form the predominant lithotype as for example, hornblende gneisses banded that occur in Búzios and in Araruama towns.

Gneisses with granodioritic composition constitute the most common lithotype of Região dos Lagos Complex, such as the coastal region between Macaé and Rio das Ostras, between Peró and Cabo Frio regions, and in the Serra do Segredo region near the basal contact with the Cabo Frio Terrane. These rocks are leucocratic to mesocratic, with quartz-feldspatic lenses. Its main mineralogy is given by quartz, orthoclase, microcline, plagioclase, biotite and subordinate hornblende. Opaque phases, apatite and zircon are common accessory minerals.

Gneisses of tonalitic composition and enclaves of dioritic rocks are common, both in metric to centimetric ranges in orthogneisses, and enclaves, suggesting autholitic origin. The mineralogy comprises quartz, plagioclase and K-feldspar and in smaller proportions, hornblende, biotite and locally clinopyroxene. Farther South of the Cabo Frio Terrane, foliated granitoids predominate, with composition ranging from sieno- to monzogranite, and more rarely quartzmonzonite, presenting locally preserved porphyritic texture, with k-feldspar megacrystals up to $8 \mathrm{~cm}$. They are common in Araruama (Suite Araruama, Schmitt et al., 2012b), although they occur subordinately in the Cabo Frio region. Biotite and hornblende are common mafic phases.

Amphibolites occur as tabular bodies on boudinage lenses, ranging in size from decametric to centimetric. Rock contact are always sharpe, and coupled with bodies geometry suggests that these rocks could represent intrusive episodes in the orthogneisses (dykes and sills). Its mineralogy comprises plagioclase and hornblende in addition to diopside, titanite, apatite, zircon and opaque minerals. In the region near Macaé there is a body of meta-gabbro, composed by augite, plagioclase and accessory minerals (Fe oxides and sulfide).

The basement rocks represent this important magmatism and comprise more than a half of the exposed outcrops in the Cabo Frio Terrane (Fig. 2), a significant area in the Rio de Janeiro State. The ages presented here vary from1989 Ma to1942 Ma. Magmatic rocks of equivalent ages are not known in the other areas of Ribeira Belt. An important conclusion of these magmatic ages of Região dos Lagos Complex is the correlation with the magmatism of the Congo Craton (in Africa), which suggests the São Francisco-Congo collision. In the literature, this collision occurred in the Neoproterozoic, during the amalgamation of the Gondwana Supercontinent. The Cabo Frio Terrane would have belonged to the Congo Craton, and after the collision with the São Francisco Craton during the opening of the Atlantic Ocean, these rocks remained on the South American Continent. According to Kröner et al. (2010) the magmatic zircon ages of the basement rocks in Namibia region range from $1861 \pm 3$ to $1758 \pm 3$ Ma. McCourt et al. (2013) proposed the continuity of these crustal blocks prior to Gondwana breakup based on links between the Ribeira Belt in the Brazilian counterpart and the West Congo Belt where granitic magmatism occurred at $2.0 \pm 0.04 \mathrm{Ga}$. This magmatism is part of a Palaeoproterozoic granitoid event recognized throughout the southern Angola region and was probably linked to an active continental margin of that age. Seth et al. (1998) reported crystallization ages of gneiss protoliths from 2645 to $2585 \mathrm{Ma}$, and they represent the oldest ages so far found in Namibia. The authors also characterized a thermal event at ca. $2285 \mathrm{Ma}$ that caused new zircon growth in the Archaean rocks and major igneous activity between $1985 \mathrm{Ma}$ and $1960 \mathrm{Ma}$, represented by granitoid intrusions. This demonstrates that these gneisses were part of the Congo Craton since the Palaeoproterozoic.

\subsection{Implications for the Ribeira Belt evolution}

The geological evolution in the regional context can be sketched from the rocks observed in the study area and its correlations with lithological units that occur in the central portion of the Ribeira Belt (Fig. 2). Thus, the proposed geological evolution presented in this work is supported by $\mathrm{U}-\mathrm{Pb}$ data here reported and information obtained in the literature, which includes descriptions of lithostratigraphic units, geochronological, geochemical and structural data (Noce et al., 2007; Monié et al., 2012; McCourt et al., 2013; Costa et al., 2017). In this way, the results also characterize 
an important magmatic event related to the Ribeira Belt basement, formed previously to the Gondwana amalgamation and is probably related to the Congo Craton basement (Seth et al., 1998, 2003; De Waele et al., 2008; Kröner et al., 2010). This collision (Fig. 8) may have been diachronic, with the development of ridges, deformation, metamorphism, continental crust duplication, and orogenic processes. In the Costeiro Terrane, the thrusting put in contact paraderived rocks of the São Fidelis Unit and the Rio Negro Complex, formed during the pre-collision period. In the Occidental Terrane, rocks of the basement represented by the Juiz de Fora Complex were thrusted the paragneiss of the Paraíba do Sul Group and the Italva Complex. One product of this collision accompanied by thrusting was the increase in temperature and pressure, with the alteration of the mineral paragenesis of the protoliths and the formation of new metamorphic minerals.

In the Cabo Frio Terrane, the new paragenesis formed during the metamorphic process points to medium to highgrade metamorphism between the green and the amphibolitic facies. Locally, granulitization processes suggest high temperatures and pressure, indicating the possible duplication of the crust, inferred by the mineral paragenesis of granulite facies. The rocks may have reached depths greater than $20 \mathrm{~km}$ and temperatures of up to $800^{\circ} \mathrm{C}$ (Schmitt et al., 2008). In hydrated portions, high-grade metamorphism resulted in partial melting of the rocks, causing the formation of in situ magmas and crystallization of anatexites. In this case, granitic rocks were formed in large volume due to partial melting of the metassediments of the São Fidelis Unit and due to their great extension, were mapped on the 1: 100.000 scale.

The deformation also resulted in folds (open, closed, sheath, among others), foliations well marked by orientations of new minerals, micas lineaments, besides compositional banding due to partial melting and segregations between felsic liquids and formation of enriched bands of mafic minerals. Migmatite features are observed, as well schlieren and nebulitic types and others, attesting to high-grade metamorphic processes during the collision process.

The slow cooling of the orogen from its collapse is reversed with the approximation of the allochthonous terrane represented by the Cabo Frio Terrane, whose collision (Fig. 7) allowed the reheating and deformation that characterize Búzios Orogeny and subsequent collapse. The consequences in the interior of the Craton are simple regional folds, but in the area of collision its noteworthy structures record the deep collision.

In the suture zone, the juxtaposition of distinct metasedimentary rocks, represented by the Búzios Unit (Cabo Frio Terrane) and by the São Fidelis Unit (Oriental Terrane). In addition, the paragneisses rocks of the Búzios Formation are accompanied by the Paleoproterozoic gneiss basement of the Região dos Lagos Complex. These orthogneisses are also locally in contact with the metassediments of the São Fidelis Unit, thus characterizing a suture with thrusting geometry between two terrains with distinct histories.

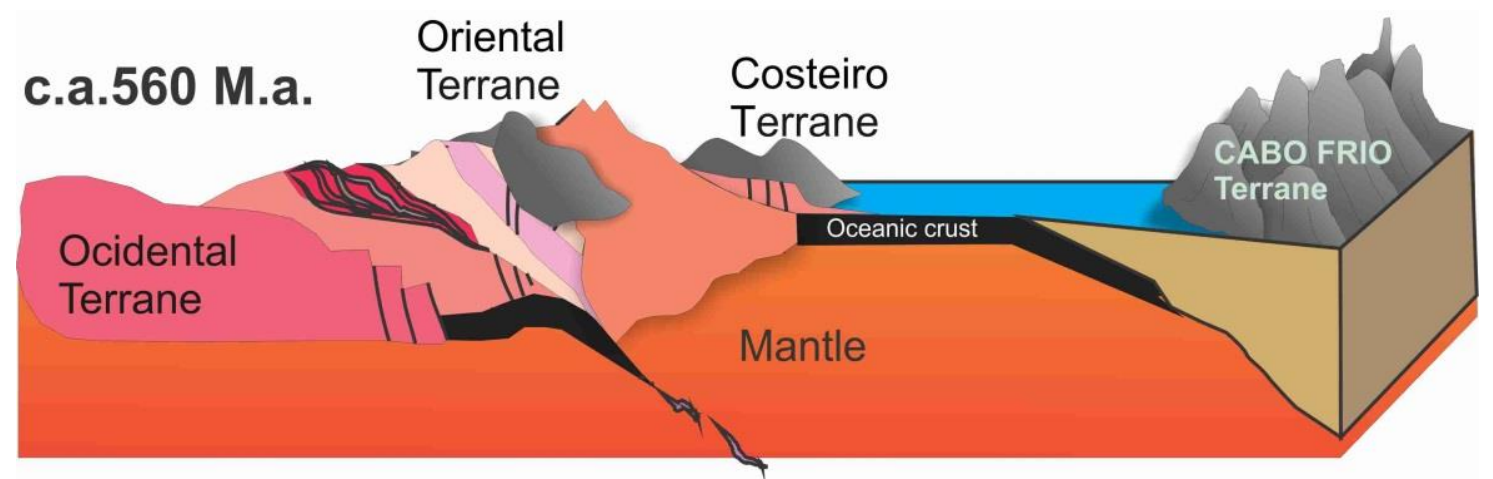

Fig. 8. Collision between Oriental terrene and Cabo Frio Terrene at $560 \mathrm{Ma}$.

\section{Conclusion}

The specific targets of this investigation were the $\mathrm{U}-\mathrm{Pb}$ (SHRIMP) crystallization age of Cabo Frio Terrane basement rocks to understand the origin of the Região dos Lagos rocks. The results here reported allowed to identify the crystallization ages of this complex. The obtained $\mathrm{U}-\mathrm{Pb}$ ages are in the range from $1942 \pm 16 \mathrm{Ma}$ to $1986 \pm 24 \mathrm{Ma}$. These results suggest that the Região dos Lagos complex mantlederived rocks were formed during an important magmatic event related to Congo craton basement formed previously to the Gondwana amalgamation. In this way, the ages here presented cannot be related to the Ribeira Belt basement comprised of Juiz de Fora Complex rocks. According to literature, the ages of the implantation of Serrinha magmatic arc, which is associated with the Mineiro Belt, proposed by Ávila (2010), are in the range of about 2230-2080 Ma.

The results here reported also indicate important features for the Ribeira Belt evolution. For example, the 
characterization of Cabo Frio Terrane supracrustals defines different features for Neoproterozoic crustal evolution compared with the Costeiro Terrane. The sedimentary cover of the Cabo Frio Terrane is represented by the supracrustal sequence, comprised of the Búzios-Palmital metasedimentary rocks which were metamorphosed at granulitic facies. In Costeiro Terrane, the supracrustal units are comprised of São Fidelis and Italva rocks defined as high amphibolitic metamorphic rocks.

\section{Acknowledgment}

The authors acknowledge the MultiLab (UERJ) for sample preparation and mounts elaboration. SHRIMP facilities at Curtin University was important to the conclusion of this work. MCG thanks CNPq for post-doctoral fellowship (process 229946/2013-5).

\section{References}

Almeida, J., Heilbron, M., Pascutti, A.H.F.G., Silva, T.M., Tupinambá, M., Dios, F., Silva, L.G.E., Valeriano, C., Duarte, B., Schmitt, R.S., Valladares, C.S., Nogueira, J.R., Ragatky, C.D., Valente, S., Souza, D.M., Azevedo, R., Costa, M., Viana, S.M., Geraldes, M.C., Souza, M.P.G., Martins, M.A.M., Menezes, P.T.L., Mane, M.A., Martins, P., Carvalho, F.H., Mello, R.P., Palermo, N., Guimarães, P.V., Silva, F.L., 2009. Мapa Geológico da Folha Macaé SF.24-Y-A- I. Belo Horizonte: CPRM, CD-ROM.

Ávila, C.A., Teixeira, W., Cordani, U.G., Moura, C.A.V., Pereira, R.M., 2010. Rhyacian (2.23-2.20) juvenile accretion in the Southern São Francisco craton, Brazil: Geochemical and isotopic evidence from the Serrinha magmatic suíte, Mineiro belt. Journal of South American Earth Sciences 29, 464-482. https://doi.org/10.1016/j.jsames.2009.07.009

Black, L.P., Kamo, S.L., Allen, C.M., Aleinkoff, J.N., Davis, D.W., Korsch, R.J., Foudoulis, C., 2003. TEMORA 1: a new zircon standard for Fanerozoic U-Pb geochronology. Chemical Geology 200, 155-170. https://doi.org/10.1016/S00092541(03)00165-7

Compston, W., Williams, I. S., Kirschvink, J.L., Zhang, Z., Ma, G., 1992. Zircon U-Pb age from the Early Cambrian time-scale. Journal of the Geological Society149, 171184.https://doi.org/10.1144/gsigs.149.2.0171

Costa, R.V., Trouw, R.A.J., Mendes, J.C., Geraldes, M., 2017. Proterozoic evolution of part of the Embu Complex, eastern São Paulo state, SE Brazil. Journal of South American Earth Sciences $\quad 79, \quad$ 170-188.https://doi.org/10.1016/ j.jsames.2017.08.003

Delhal, J., Ledent, D., Cordani, U., 1969. Ages Pb/U, Sr/Rb et $\mathrm{Ar} / \mathrm{K}$ de Formations Métamorphiques et GranitiqueduSudEstduBrésil (Etats de Rio de Janeiro et Minas Gerais). Annales de la Société Géologique de Belgique 92, 271-283.

De Waele, B., Johnson, S.P, Pisarevsky, S.A., 2008. Palaeoproterozoic to Neoproterozoic growth and evolution of the eastern Congo Craton: Its role in the Rodinia puzzle. Precambrian Research 160, 127-141. https://doi.org/10.1016/j.precamres.2007.04.020
Duarte, B.P., Heilbron, M., Campos, M., 2000. Granulite/Charnockite from the Juiz de Fora Domain, Central Segment of the Brasiliano-Pan-African Ribeira Belt. Revista. Brasileira de Geociências 30(3), 358-362.

Fonseca, M.J.G. 1998. Mapa geológico do Estado do Rio de Janeiro: texto explicativo. Rio de Janeiro: DNPM, 141p. Escala 1:400.000.

Fonseca, A.C., 1994a. Esboço Geocronológico da Região de Cabo Frio, Estado do Rio de Janeiro, PhD Thesis, (Doutorado)Departamento de Geologia, Universidade de São Paulo, São Paulo, 186 p.

Fonseca, A.C., 1994b. Fragmento tectônico Cabo Frio: aspectos de campo, petrografia e geoquímica. Anuário do Instituto de Geociências, UFRJ, 17, 109-131.

Geraldes, M.C., Motoki, A., Costa, A., Mota, C.E., Mohriak, W.U., 2013. Geochronology (Ar/Ar and K-Ar) of the South Atlantic post-break-up magmatism. In: Mohriak, W.U., Danforth, A., Post, P.J., Brown, D.E., Tari, G.C., Nemčok, M., Sinha, S.T. (eds.), Conjugate Divergent Margins Geological Society, London, Special Publications, 369, 41-74.

Geraldes, M.C., Heilbron, M., Pascutti, A.H.F.G., Silva, T.M., Meneses, P.T., Valladares, C.S., Almeida, J.C.H., Duarte, B.P., Tupinambá, M., Nogueira, J.R., Valeriano, C., Silva, L.G.E., Schmitt, R.S., Ragatky, C.D., Nummer, A.R., Valente, S.C., Dios, F.B., Pamplona, M.D., Silva, M., Saliba, F., Mello, F.M., Palermo, N., Mello, R.P., Guimarães, P.V., Silva, F.L., 2009. Mapa Geológico da Folha Casemiro de Abreu SF.23-Z-B-III. Belo Horizonte: CPRM, CD-ROM.

Geraldes, M.C., 2010. Introdução à Geocronologia. SBG Sociedade Brasileira de Geologia, 135 p.

Heilbron, M., 2004. Província Mantiqueira. In: Mantesso-Neto, V., Bartorelli, A., Carneiro, C.D.R., Brito-Neves, B.B. (eds). Geologia do continente sul-americano: evolução da obra de Fernando Flávio Marques de Almeida. Editora Beca. São Paulo, 203-235.

Heilbron, M., Machado, N., 2003. Timing of terrane accretion in the Neoproterozoic-Eopaleozoic Ribeira Belt (SE Brazil). Precambrian Research, 125 (1/2), 87 - 112. https://doi.org/10.1016/S0301-9268(03)00082-2

Heilbron, M., Valeriano, C.M., Valladares, C.S., Machado, N., 1995. A Orogênese Brasiliana no segmento central da Faixa Ribeira, Brasil. Revista Brasileira de Geociências 25(4), 249-266.

Heilbron, M., Simões, L.S.A, Alves, R.P., Chrispim, S.J., 1974. Geologia do Cabo dos Búzios. Anais da Academia Brasileira de Ciências, Rio de Janeiro, 54 (3), 553-562.

Leonardos Jr, O.H., Fyfe, W.S., 1974. Ultrametamorphism and melting of a continental margin: The Rio de Janeiro Region, Brazil. Contributions to Mineralogy and Petrology 46, 201-214.

Ludwig, K. R. 2003. Isoplot 3.00: A Geochronological Tookkit for Microsoft Excel. Berkeley Geochrnological Center, Spec Publ $\mathrm{N}^{\mathrm{o}}$. 4, 70 p.

Kröner A., Rojas-Agramonte Y., Hegner E., Hoffman K.-H., Wingate M.T.D. 2010. SHRIMP zircon dating and Nd isotopic systematics of Paleoproterozoic migmatit orthogneisses in the Epupa Metamorphic Complex of northwest Namibia. Precambrian Research 183, 50-69. https://doi.org/10.1016/j.precamres.2010.06.018

Machado, N., Valladares, C., Heilbron, M., Valeriano, C., 1996. U$\mathrm{Pb}$ geochronology of the central Ribeira Belt (Brazil) and implications for the evolution of the Brazilian Orogeny. 
Precambrian Research 79,

https://doi.org/10.1016/0301-9268(95)00103-4

Machado R., Demange, M., 1990. Reinterpretação estrutural e tectônica da região leste da Baía da Guanabara e a definição do Batólito de Araruama (RJ). Anais Congresso Brasileiro Geologia, SBG, 36, Natal (RN), 2744-2754.

McCourt S., Armstrong R.A., Jelsma H., Mapeo R.B.M. 2013. New $\mathrm{U}-\mathrm{Pb}$ SHRIMP ages from the Lubango region, SW Angola: insights into the Paleoproterozoic evolution of the Angolan Shield, southern Congo Craton, Africa. Journal of the Geological Society of London 170, 353363.https://doi.org/10.1144/jgs2012-059.

Monié, P., Bosch, D., Bruguier, O., Vauchez A., Rolland Y., Nsungani, P., Buta Neto, A., 2012. The Late Neoproterozoic/Early Palaeozoic evolution of the West Congo Belt of NW Angola: geochronological (U-Pb and Ar-Ar) and petrostructural constraints. Terra Nova 24(3), 238-247.

Noce, C., Pedrosa-Soares, A,.Silva, L.C., Armstrong, R., Piuzana, D., 2007. Evolution of polycyclic basement complexes in the Araçuaí Orogen, based on U Pb SHRIMP data: Implications for Brazil Africa links in Paleoproterozoic time?. Precambrian Research 159, 60-78. https://doi.org/10.1016/i.precamres. 2007.06.001

Reis, A.P., 1995. Carta Geológica do Estado do Rio de Janeiro: Sinopse geológica do Estado do Rio de Janeiro.Mapa Geológico 1:400.000, Niteroi, DRM, 60 p.

Reis, A.P., Nunes, H.H.R., Chiavegatto, J.R.S., Lima, P.R.A., Rocha, R.L.S., 1980. Projeto Carta Geológica do Estado do Rio de Janeiro: Geologia e Recursos Minerais das Folhas de Cabo Frio e Farol do Cabo. Niterói, DRM-RJ.

Rosier, G. F. A 1965 Pesquisas geológicas na parte oriental do Estado do Rio de Janeiro e na parte vizinha de Minas Gerais. Rio de Janeiro: DNPM-DGM Boletim 222, 40 p.

Rosier, G.F., 1957. A geologia da Serra do Mar, entre os picos de Maria Comprida e do Desengano (Estado do Rio de Janeiro), DNPM-DGM Boletim 116, 58 p.

Seth, B., Armstrong, R.A., Brandt, S., Villa, I., Kramers, J.D., 2003. Mesoproterozoic $\mathrm{U}-\mathrm{Pb}$ and $\mathrm{Pb}-\mathrm{Pb}$ ages of granulites in $\mathrm{NW}$ Namibia: reconstructing a complete orogenic cycle. Precambrian Research 126, 147-168. https://doi.org/10.1016/S03019268(03)00193-1

Seth, B., Kröner, A., Mezger, K., Nemchin, A.A., Pidgeon, R.T., Okrusch, M., 1998. Archean to Neoproterozoic magmatic events in the Kaoko Belt of NW Namibia and their geodynamic significance. Precambrian Research 92, 341-363. https://doi.org/10.1016/S0301-9268(98)00086-2

Schmitt, R.S., Trouw, R.A.J., Passchier, C.W., Medeiros, S.R., Armstrong, R.A., 2012a. 530 Ma syntectonic syenites and granites in NW Namibia - Their relation with collision along the junction of the Damara and Kaoko Belts. Gondwana Research 21, 362-377. https://doi.org/10.1016/j.gr.2011.08.006

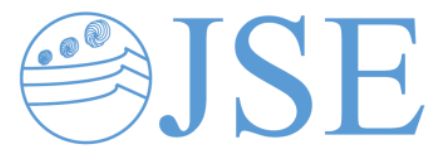

RESEARCH PAPER

Schmitt, R.S., Mansur, K.L., Guerra, J.V., Góes, N.F.B., Silva, R.S., Ramos, A.S., Machado, G.M.F., Savi, D.C., Geraldes, M.C., Medeiros, S.R., Moraes, J.M., Silva, C.B., Matta, P.B., Toledo, P.P., Motoki, A., Sichel, S., Guimarães, P.V., Silva, F.L., Palermo, N., Pereira, R.M., Meneses, P.T., 2012b. Mapa Geológico da Folha Cabo Frio SF.23-Z-B-VI. Belo Horizonte: CPRM, CD-ROM.

Schmitt, R.S., Trouw, R.A.J., Medeiros, S.R., Dantas, E.L., 2008. Age and geotectonic setting of Late-Neoproterozoic juvenile mafic gneisses and associated paragneisses from the Ribeira Belt (SE Brazil): geochemistry and Sm-Nd data - implications on Gondwana assembly. Gondwana Research 13, 502-515. https://doi.org/10.1016/j.gr.2007.05.015

Schmitt, R.S., 2001. Orogenia Búzios - Um evento tectonometamórfico cambro-ordoviciano caracterizado no Domínio Tectônico de Cabo Frio, Faixa Ribeira - sudeste do Brasil. PhD Thesis, Instituto de Geociências, Universidade Federal do Rio de Janeiro, 273p.

Silva, L.C. da, Armstrong, R., Noce, C.M., Pimentel, M., PedrosaSoares, A.C., Leite, C., Vieira, V.S., Paes, V.C., 2002. Reavaliação U-Pb SHRIMP em terrenos pré-cambrianos brasileiros. Parte II: Orógeno Araçuaí, Cinturão Mineiro e Cráton São Francisco Meridional. Revista Brasileira de Geociências 32 (4), 513-552.

Trompette R. 1994. Geology of Western Gondwana (2000 - 500 Ma) A.A. Balkema Rotterdam, 350 pp.

Trouw, R.A.J., Heilbron, M., Ribeiro, A., Paciullo, F., Valeriano, C., Almeida, J.C.H., Tupinambá, M., Andreis, R.R., 2000. The central segment of the Ribeira Belt: Cordani U.G., Milani E.J., Thomaz-Filho A., Campos D.A. (eds.),TectonicEvolution of South America, $31^{\text {st }}$ International Geological Congress, Rio de Janeiro, Brazil, pp. 287-310.

Tupinambá, M., Machado, N., Heilbron, M., Ragatky, C.D., 2007. Meso-Neoproterozoic lithospheric extensional events in the São Francisco Craton and its Surrounding South American and African metamorphic Belts. Revista Brasileira de Geociências 37, 87-91.

Viana, S.M., 2008. Evolução Geológica do Terreno Paraíba do Sul, Orógeno Ribeira, sudeste do Brasil, com base em estudos litogeoquímicos e de geocronologia U-Pb (LA-ICPMS). PhD Thesis, Faculdade de Geologia, Universidade do Estado do Rio de Janeiro, $230 \mathrm{p}$.

Viana, S.M., Valladares, C.S., Duarte, B.P., 2008. Geoquímica dos ortognaisses do Complexo Região dos Lagos, Araruama-Cabo Frio, Rio de Janeiro, Brasil. Revista Brasileira de Geociências, 27(1), 111-120.

Zimbres, E., Kawashita, K., Van Schmus, W.R., 1990. Evidências de um núcleo Transamazônico na Região de Cabo Frio, RJ e sua correlação com o cráton de Angola, Africa. Congresso Brasileiro de Geologia, 36, Sociedade Brasileira de Geologia. Natal, Brazil, pp. 2735-2743. 
Appendix 1. Analytical data.

\begin{tabular}{|c|c|c|c|c|c|c|c|c|c|c|c|c|c|c|c|c|c|c|c|c|}
\hline analysis & $204 / 206$ & err & $207 / 206$ & err & $208 / 206$ & err & $238 / 206$ & err & $206 / 238$ & err & $204 / 238$ & err & $238 / 204$ & err & $206 \mathrm{~Pb} / 238 \mathrm{U}(\mathrm{f})$ & err & $\operatorname{ppm} \mathbf{U}$ & err & $232 \mathrm{Th} / 238 \mathrm{U}$ & err \\
\hline CRL04-1.1 & $1.00 \mathrm{E}-32$ & $1.00 \mathrm{E}-32$ & 0.1185019 & 0.00092 & 0.162632 & 0.00186 & 0.25835 & 0.001844 & 0.507314 & 0.00289 & 5.92728 & 0.031531 & 0.54641 & 0.0021567 & 0.014282 & 0.000155 & 0.07915 & 0.0009 & 0.58578 & 0.002507 \\
\hline CRL04-2.1 & $1.00 \mathrm{E}-32$ & $1.00 \mathrm{E}-32$ & 0.1222206 & 0.00077 & 0.196723 & 0.00169 & 0.33626 & 0.002228 & 0.572527 & 0.0028 & 5.9352 & 0.027901 & 0.642738 & 0.0022094 & 0.015921 & 0.000153 & 0.10321 & 0.001 & 0.68905 & 0.00255 \\
\hline CRL04-3.1 & $-2.074 \mathrm{E}-22$ & $3.21 \mathrm{E}-14$ & 0.1195385 & 0.00084 & 0.272269 & 0.00223 & 0.26066 & 0.001859 & 0.611795 & 0.00337 & 6.11086 & 0.032252 & 0.91122 & 0.0032851 & 0.01618 & 0.000174 & 0.07877 & 0.0009 & 0.98264 & 0.003763 \\
\hline CRL04-4.1 & $1.00 \mathrm{E}-32$ & $1.00 \mathrm{E}-32$ & 0.1234905 & 0.00096 & 0.227052 & 0.00228 & 0.2181 & 0.001647 & 0.581489 & 0.00354 & 6.06432 & 0.034991 & 0.733525 & 0.0029581 & 0.015574 & 0.000183 & 0.06589 & 0.0008 & 0.78989 & 0.003411 \\
\hline CRL04-6.1 & $2.41893 \mathrm{E}-05$ & $2.42 \mathrm{E}-05$ & 0.1223376 & 0.00193 & 0.275692 & 0.0051 & 0.0579 & 0.000725 & 0.560658 & 0.00672 & 6.19085 & 0.068364 & 0.901341 & 0.0064628 & 0.014549 & 0.000322 & 0.01728 & 0.0004 & 0.97625 & 0.007439 \\
\hline CRL04-7.1 & $2.25224 \mathrm{E}-05$ & $9.19 \mathrm{E}-06$ & 0.1220518 & 0.00072 & 0.197373 & 0.00158 & 0.4141 & 0.00268 & 0.564432 & 0.00258 & 5.90949 & 0.026159 & 0.653379 & 0.0021387 & 0.015995 & 0.000146 & 0.12633 & 0.0011 & 0.70041 & 0.002465 \\
\hline CRL04-8.1 & 0.000603203 & 0.000148 & 0.1289919 & 0.00126 & 0.205272 & 0.00274 & 0.14934 & 0.001367 & 0.605175 & 0.00472 & 6.0745 & 0.044622 & 0.589405 & 0.0030874 & 0.016127 & 0.000238 & 0.045 & 0.0007 & 0.63474 & 0.003591 \\
\hline CRL04-9.1 & $-6.184 \mathrm{E}-06$ & $6.18 \mathrm{E}-06$ & 0.118176 & 0.00092 & 0.152705 & 0.00179 & 0.28201 & 0.002112 & 0.537291 & 0.00312 & 6.18411 & 0.033887 & 0.48708 & 0.0020043 & 0.013859 & 0.000154 & 0.08373 & 0.0009 & 0.52639 & 0.00235 \\
\hline CRL04-10.1 & 0.001078881 & 0.000112 & 0.1341747 & 0.00079 & 0.231845 & 0.0018 & 0.45526 & 0.002841 & 0.451391 & 0.002 & 5.44641 & 0.023105 & 0.625333 & 0.0020339 & 0.015115 & 0.000133 & 0.14615 & 0.0012 & 0.66028 & 0.002325 \\
\hline CRL05-1.1 & $1.38624 \mathrm{E}-05$ & $9.8 \mathrm{E}-06$ & 0.1230826 & 0.001 & 0.068793 & 0.00126 & 0.23187 & 0.001828 & 0.574095 & 0.00363 & 6.13589 & 0.036798 & 0.246721 & 0.0012971 & 0.015145 & 0.000184 & 0.06905 & 0.0008 & 0.26621 & 0.001564 \\
\hline CRL05-2.1 & $1.00 \mathrm{E}-32$ & $1.00 \mathrm{E}-32$ & 0.1195729 & 0.00109 & 0.130171 & 0.00193 & 0.18207 & 0.001585 & 0.633063 & 0.00454 & 6.3285 & 0.043211 & 0.432074 & 0.0022225 & 0.015699 & 0.000216 & 0.05316 & 0.0008 & 0.46922 & 0.002634 \\
\hline CRL05-3.1 & $1.10816 \mathrm{E}-05$ & $1.11 \mathrm{E}-05$ & 0.1220167 & 0.00125 & 0.282293 & 0.00333 & 0.14917 & 0.001423 & 0.629429 & 0.00511 & 6.07468 & 0.046917 & 0.930517 & 0.0047814 & 0.016829 & 0.000262 & 0.04472 & 0.0007 & 1.00247 & 0.005469 \\
\hline CRL05-4.1 & $1.00 \mathrm{E}-32$ & $1.00 \mathrm{E}-32$ & 0.1232899 & 0.00151 & 0.201206 & 0.00333 & 0.09834 & 0.001099 & 0.664014 & 0.00662 & 6.27685 & 0.059425 & 0.68313 & 0.0044134 & 0.016786 & 0.000319 & 0.02878 & 0.0006 & 0.74049 & 0.005128 \\
\hline CRL05-5.1 & $1.00 \mathrm{E}-32$ & $1.00 \mathrm{E}-32$ & 0.1229088 & 0.00116 & 0.389587 & 0.00374 & 0.19516 & 0.001757 & 0.59112 & 0.00436 & 6.07502 & 0.042574 & 1.289383 & 0.0058519 & 0.015515 & 0.00022 & 0.05842 & 0.0008 & 1.38879 & 0.006618 \\
\hline CRL05-6.1 & 7.8544E-06 & 5.55E-06 & 0.1185768 & 0.00074 & 0.024359 & 0.00056 & 0.52488 & 0.003645 & 0.504163 & 0.00235 & 5.97519 & 0.026809 & 0.07722 & 0.0004444 & 0.013935 & 0.000129 & 0.15992 & 0.0014 & 0.08294 & 0.000552 \\
\hline CRL05-7.1 & $1.00 \mathrm{E}-32$ & $1.00 \mathrm{E}-32$ & 0.1192304 & 0.00135 & 0.227254 & 0.00323 & 0.13362 & 0.001371 & 0.630338 & 0.00559 & 6.19407 & 0.052007 & 0.733962 & 0.0042033 & 0.016377 & 0.000277 & 0.03965 & 0.0007 & 0.7937 & 0.004864 \\
\hline CRL05-8.1 & 0.00037251 & $6.92 \mathrm{E}-05$ & 0.1248561 & 0.00081 & 0.163634 & 0.00159 & 0.47005 & 0.003436 & 0.53877 & 0.0027 & 6.2767 & 0.03017 & 0.563658 & 0.0020328 & 0.013567 & 0.000134 & 0.13799 & 0.0013 & 0.61161 & 0.002373 \\
\hline CRL05-9.1 & $-2.0301 \mathrm{E}-05$ & 2.03E-05 & 0.1213867 & 0.00168 & 0.317311 & 0.0048 & 0.10222 & 0.001202 & 0.58349 & 0.0062 & 6.20208 & 0.061567 & 1.000919 & 0.0064356 & 0.01501 & 0.000299 & 0.03019 & 0.0006 & 1.08254 & 0.007355 \\
\hline CRL05-10.1 & $-1.0787 \mathrm{E}-13$ & 1.08E-09 & 0.1211204 & 0.00123 & 0.245931 & 0.00305 & 0.18617 & 0.001817 & 0.621508 & 0.00498 & 6.31308 & 0.047966 & 0.82609 & 0.0042325 & 0.015221 & 0.000233 & 0.05439 & 0.0009 & 0.89625 & 0.004879 \\
\hline CRL06-1.1 & $1.00 \mathrm{E}-32$ & $1.00 \mathrm{E}-32$ & 0.1259602 & 0.00282 & 0.252461 & 0.00695 & 0.04417 & 0.00075 & 0.518647 & 0.00866 & 5.90314 & 0.089945 & 0.784606 & 0.0080194 & 0.014605 & 0.000448 & 0.01355 & 0.0004 & 0.84041 & 0.009209 \\
\hline CRL06-2.1 & $6.88985 \mathrm{E}-06$ & $6.89 \mathrm{E}-06$ & 0.1593943 & 0.00116 & 0.068555 & 0.00124 & 0.22478 & 0.00209 & 0.815155 & 0.00582 & 6.34968 & 0.044709 & 0.232969 & 0.0014437 & 0.019961 & 0.000284 & 0.06535 & 0.0009 & 0.25309 & 0.001754 \\
\hline CRL06-3.1 & $1.55153 \mathrm{E}-05$ & $1.55 \mathrm{E}-05$ & 0.122771 & 0.00147 & 0.144452 & 0.00272 & 0.13895 & 0.001505 & 0.595727 & 0.00557 & 6.12303 & 0.05403 & 0.508289 & 0.0032839 & 0.015499 & 0.000276 & 0.04158 & 0.0008 & 0.54841 & 0.00385 \\
\hline CRL06-4.1 & $7.71926 \mathrm{E}-06$ & 5.46E-06 & 0.1733424 & 0.00092 & 0.101499 & 0.00114 & 0.40881 & 0.003339 & 0.836083 & 0.00457 & 6.30499 & 0.034892 & 0.340272 & 0.001534 & 0.020643 & 0.000234 & 0.11982 & 0.0013 & 0.36929 & 0.001826 \\
\hline CRL06-5.1 & $1.00 \mathrm{E}-32$ & $1.00 \mathrm{E}-32$ & 0.1688623 & 0.00126 & 0.081144 & 0.00143 & 0.20474 & 0.002015 & 0.853561 & 0.00651 & 6.23458 & 0.047168 & 0.276507 & 0.0017649 & 0.021612 & 0.000331 & 0.06062 & 0.0009 & 0.29946 & 0.002127 \\
\hline CRL06-6.1 & $1.68324 \mathrm{E}-05$ & 1.68E-05 & 0.1653675 & 0.00185 & 0.119905 & 0.00258 & 0.08679 & 0.001158 & 0.924929 & 0.01075 & 6.62831 & 0.075566 & 0.451742 & 0.0037353 & 0.021277 & 0.000483 & 0.02449 & 0.0006 & 0.49516 & 0.004453 \\
\hline
\end{tabular}


Appendix 1 (cont.). Analytical data.

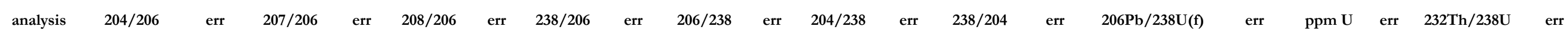

$\begin{array}{lllllllllllllllll}\text { CRL06-7.1 } & 1.00 \mathrm{E}-32 & 1.00 \mathrm{E}-32 & 0.1199663 & 0.00134 & 0.093762 & 0.002 & 0.15506 & 0.001712 & 0.709027 & 0.00655 & 6.62822 & 0.058726 & 0.304453 & 0.0021689\end{array}$ $\begin{array}{llllllllllllllll}\text { CRL06-8.1 } & 0.000216803 & 9.7 \mathrm{E}-05 & 0.1209062 & 0.00259 & 0.142382 & 0.00477 & 0.05395 & 0.000908 & 0.567404 & 0.00917 & 6.5094 & 0.096121 & 0.451988 & 0.0048324\end{array}$ $\begin{array}{lllllllllllllll}\text { CRL96-9.1 } & 1.00 \mathrm{E}-32 & 1.00 \mathrm{E}-32 & 0.1308997 & 0.00132 & 0.08301 & 0.00175 & 0.19677 & 0.002025 & 0.644122 & 0.00536 & 6.24033 & 0.049801 & 0.281933 & 0.0018894\end{array}$ $\begin{array}{llllllllllllllll}\text { CRL06-10.1 } & 1.00 \mathrm{E}-32 & 1.00 \mathrm{E}-32 & 0.1215504 & 0.00124 & 0.40358 & 0.00409 & 0.18151 & 0.001958 & 0.752363 & 0.00651 & 6.63579 & 0.055533 & 1.34161 & 0.0070746\end{array}$ $\begin{array}{llllllllllllllll}\text { CRL07-1.1 } & 1.66365 \mathrm{E}-05 & 1.66 \mathrm{E}-05 & 0.1169133 & 0.00154 & 0.350443 & 0.00477 & 0.07018 & 0.000727 & 0.55261 & 0.0054 & 5.64512 & 0.051238 & 1.154681 & 0.0067895\end{array}$ $\begin{array}{llllllllllllllll}\text { CRL07-2.1 } & 1.00 \mathrm{E}-32 & 1.00 \mathrm{E}-32 & 0.1197225 & 0.00094 & 0.277627 & 0.00253 & 0.19367 & 0.001394 & 0.559129 & 0.00334 & 6.05123 & 0.033925 & 0.926462 & 0.0034917\end{array}$ $\begin{array}{llllllllllllllll}\text { CRL07-3.1 } & 1.00 \mathrm{E}-32 & 1.00 \mathrm{E}-32 & 0.1219172 & 0.00226 & 0.532758 & 0.00872 & 0.03501 & 0.000504 & 0.576579 & 0.00814 & 5.95024 & 0.077873 & 1.700739 & 0.0134819\end{array}$ $\begin{array}{lllllllllllllllll}\text { CRL07-4.1 } & 1.00 \mathrm{E}-32 & 1.00 \mathrm{E}-32 & 0.1194982 & 0.00113 & 0.146263 & 0.00212 & 0.14598 & 0.001173 & 0.536635 & 0.00377 & 5.82507 & 0.038205 & 0.492956 & 0.0024166\end{array}$ $\begin{array}{lllllllllllllllll}\text { CRL07-5.1 } & 1.00 \mathrm{E}-32 & 1.00 \mathrm{E}-32 & 0.1210462 & 0.00208 & 0.23933 & 0.00512 & 0.04327 & 0.000573 & 0.560738 & 0.00729 & 5.7874 & 0.070248 & 0.763367 & 0.0062982\end{array}$ $\begin{array}{lllllllllllllll}\text { CRL07-6.1 } & 1.00 \mathrm{E}-32 & 1.00 \mathrm{E}-32 & 0.1181158 & 0.00219 & 0.437066 & 0.00768 & 0.03664 & 0.000531 & 0.594686 & 0.00841 & 5.8886 & 0.07779 & 1.385306 & 0.0113656\end{array}$ $\begin{array}{lllllllllllllll}\text { CRL07-7.1 } & 1.82495 \mathrm{E}-05 & 1.29 \mathrm{E}-05 & 0.122073 & 0.00117 & 0.322495 & 0.00337 & 0.12853 & 0.001107 & 0.612831 & 0.00461 & 5.95551 & 0.042375 & 1.082382 & 0.0050241\end{array}$ $\begin{array}{lllllllllllllll}\text { CRL07-8.1 } & 0.000299659 & 0.000173 & 0.112609 & 0.00353 & 0.354159 & 0.01123 & 0.02968 & 0.00047 & 0.266157 & 0.00483 & 5.59412 & 0.081495 & 0.84245 & 0.0082614\end{array}$ $\begin{array}{lllllllllllllllll}\text { CRL07-9.1 } & 1.00 \mathrm{E}-32 & 1.00 \mathrm{E}-32 & 0.1188781 & 0.002 & 0.467786 & 0.00727 & 0.05107 & 0.00065 & 0.537304 & 0.00668 & 5.92196 & 0.068108 & 1.400361 & 0.0100303\end{array}$ $\begin{array}{lllllllllllllll}\text { CRL07-10.1 } & 1.00 \mathrm{E}-32 & 1.00 \mathrm{E}-32 & 0.1179671 & 0.00098 & 0.316831 & 0.00285 & 0.18702 & 0.001426 & 0.586284 & 0.0037 & 5.97042 & 0.035599 & 1.088109 & 0.0042848\end{array}$ $\begin{array}{lllllllllllllll}\text { CRL07-11.1 } & 1.00 \mathrm{E}-32 & 1.00 \mathrm{E}-32 & 0.1198539 & 0.00121 & 0.226727 & 0.0029 & 0.16039 & 0.00135 & 0.496686 & 0.00364 & 5.9164 & 0.039986 & 0.71291 & 0.0033699\end{array}$ $\begin{array}{lllllllllllllll}\text { CRL08-1.1 } & 1.00 \mathrm{E}-32 & 1.00 \mathrm{E}-32 & 0.1171896 & 0.00099 & 0.42874 & 0.00345 & 0.2292 & 0.001648 & 0.466301 & 0.00278 & 5.79836 & 0.031929 & 1.379881 & 0.0049926\end{array}$ $\begin{array}{llllllllllllllll}\text { CRL08-2.1 } & 1.00 \mathrm{E}-32 & 1.00 \mathrm{E}-32 & 0.1203831 & 0.00168 & 0.606892 & 0.00711 & 0.06475 & 0.000727 & 0.569363 & 0.00603 & 5.70836 & 0.056335 & 2.033176 & 0.0122486\end{array}$ $\begin{array}{lllllllllllllll}\text { CRL08-3.1 } & 0.00013232 & 3.33 \mathrm{E}-05 & 0.1175133 & 0.0006 & 0.361394 & 0.0019 & 0.82429 & 0.004593 & 0.3699 & 0.00128 & 6.31115 & 0.020283 & 1.082932 & 0.0025293\end{array}$ $\begin{array}{lllllllllllllll}\text { CRL08-4.1 } & 1.00 \mathrm{E}-32 & 1.00 \mathrm{E}-32 & 0.1197979 & 0.00054 & 0.189472 & 0.00117 & 0.56872 & 0.003317 & 0.663424 & 0.00246 & 6.19155 & 0.022962 & 0.626923 & 0.0017398\end{array}$ $\begin{array}{llllllllllllllll}\text { CRL08-5.1 } & 1.00 \mathrm{E}-32 & 1.00 \mathrm{E}-32 & 0.1202077 & 0.00088 & 0.507187 & 0.00334 & 0.23827 & 0.00171 & 0.594746 & 0.00338 & 5.86111 & 0.03184 & 1.738892 & 0.0060827\end{array}$ $\begin{array}{llllllllllllllll}\text { CRL08-6.1 } & 1.00 \mathrm{E}-32 & 1.00 \mathrm{E}-32 & 0.1224881 & 0.0015 & 0.235491 & 0.00361 & 0.07972 & 0.000831 & 0.616468 & 0.00592 & 6.02636 & 0.054421 & 0.760033 & 0.0046411\end{array}$

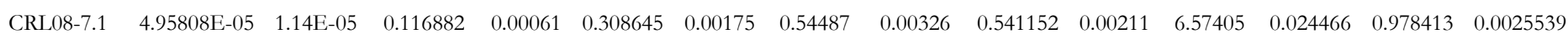
$\begin{array}{lllllllllllllll}\text { CRL08-8.1 } & 1.00 \mathrm{E}-32 & 1.00 \mathrm{E}-32 & 0.1203758 & 0.00096 & 0.359229 & 0.00299 & 0.20053 & 0.001521 & 0.595039 & 0.0037 & 5.98105 & 0.035585 & 1.185165 & 0.0046392\end{array}$ $\begin{array}{lllllllllllllll}\text { CRL08-9.1 } & 1.00 \mathrm{E}-32 & 1.00 \mathrm{E}-32 & 0.1203738 & 0.00074 & 0.190655 & 0.00161 & 0.32202 & 0.002143 & 0.628811 & 0.00309 & 6.10222 & 0.028973 & 0.642918 & 0.0022078\end{array}$ $\begin{array}{lllllllllllllllll}\text { CRL08-10.1 } & 2.65122 \mathrm{E}-05 & 1.19 \mathrm{E}-05 & 0.1210051 & 0.00084 & 0.309056 & 0.00237 & 0.38182 & 0.002558 & 0.465742 & 0.00232 & 6.00729 & 0.027916 & 1.093376 & 0.0034702\end{array}$

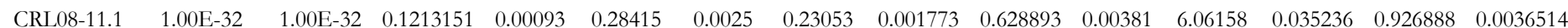

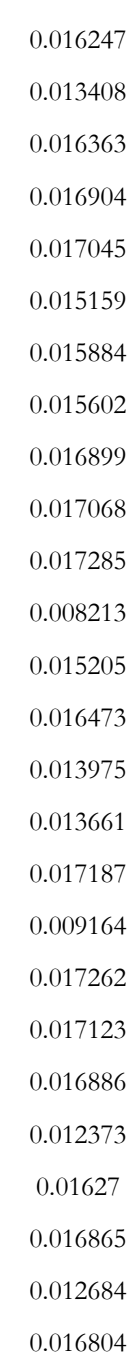
$\begin{array}{lllll}0.000396 & 0.01551 & 0.0005 & 0.4939 & 0.00576\end{array}$ $\begin{array}{lllll}0.000264 & 0.05813 & 0.001 & 0.30528 & 0.002273\end{array}$ $\begin{array}{lllll}0.000285 & 0.05161 & 0.0009 & 1.47119 & 0.008079\end{array}$ $\begin{array}{llllll}0.000314 & 0.02241 & 0.0004 & 1.22651 & 0.007656\end{array}$ $\begin{array}{lllll}0.000172 & 0.05871 & 0.0007 & 0.99733 & 0.003994\end{array}$ $\begin{array}{llllll}0.000417 & 0.01071 & 0.0003 & 1.82423 & 0.015067\end{array}$ $\begin{array}{llllll}0.000207 & 0.04534 & 0.0006 & 0.52618 & 0.002817\end{array}$ $\begin{array}{llllll}0.000411 & 0.0134 & 0.0003 & 0.81438 & 0.007215\end{array}$ $\begin{array}{lllll}0.000453 & 0.01129 & 0.0003 & 1.48402 & 0.012787\end{array}$ $\begin{array}{lllll}0.000249 & 0.03935 & 0.0006 & 1.16197 & 0.00571\end{array}$ $\begin{array}{llllll}0.000242 & 0.00949 & 0.0003 & 0.89318 & 0.009402\end{array}$ $\begin{array}{lllll}0.000349 & 0.01549 & 0.0004 & 1.49996 & 0.01125\end{array}$ $\begin{array}{lllll}0.0002 & 0.05793 & 0.0007 & 1.16888 & 0.004879\end{array}$ $\begin{array}{lllll}0.000191 & 0.04903 & 0.0007 & 0.76407 & 0.003881\end{array}$ $\begin{array}{lllll}0.000153 & 0.07117 & 0.0008 & 1.47299 & 0.005611\end{array}$ $\begin{array}{llllll}0.000345 & 0.02057 & 0.0004 & 2.16611 & 0.013634\end{array}$ $\begin{array}{lllll}6.14 \mathrm{E}-05 & 0.24103 & 0.0015 & 1.17535 & 0.002892\end{array}$ $\begin{array}{lllll}0.000132 & 0.16831 & 0.0012 & 0.67764 & 0.002015\end{array}$ $\begin{array}{llllll}0.00019 & 0.07389 & 0.0008 & 1.85971 & 0.006808\end{array}$ $\begin{array}{lllll}0.000306 & 0.02414 & 0.0005 & 0.81732 & 0.005344\end{array}$ $\begin{array}{lllll}9.6 \mathrm{E}-05 & 0.16103 & 0.0012 & 1.07188 & 0.002955\end{array}$ $\begin{array}{lllll}0.000195 & 0.06036 & 0.0007 & 1.27305 & 0.005248\end{array}$ $\begin{array}{llllll}0.000164 & 0.09729 & 0.0009 & 0.69307 & 0.002558\end{array}$ $\begin{array}{lllll}0.00012 & 0.11552 & 0.0011 & 1.17531 & 0.003942\end{array}$ $\begin{array}{lllll}0.000199 & 0.06962 & 0.0008 & 0.99792 & 0.004174\end{array}$ 
Appendix 1 (cont.). Analytical data.

\begin{tabular}{|c|c|c|c|c|c|c|c|c|c|c|c|c|c|c|c|c|c|c|c|c|}
\hline alysis & $204 / 206$ & err & $207 / 206$ & err & $208 / 206$ & err & $238 / 206$ & err & $06 / 238$ & err & $204 / 238$ & err & $238 / 204$ & err & $206 \mathrm{~Pb} / 238 \mathrm{U}(\mathrm{f})$ & err & $\mathrm{pm} \mathrm{U}$ & err & $232 \mathrm{Th} / 238 \mathrm{U}$ & err \\
\hline & & & 234179 & & & & & & & & & & & & & & & & & \\
\hline $99-2.1$ & 2037E-05 & $92 \mathrm{E}-05$ & 0.125975 & 0214 & 0.300991 & 0.00581 & 0405 & & 642414 & 0877 & 6.06972 & 7861 & 1.003008 & 0.0 & 017301 & 0446 & 01229 & 0.0003 & 1.08076 & 009408 \\
\hline J $09-31$ & $1.00 \mathrm{E}-32$ & $1.00 \mathrm{E}-32$ & 0.1234462 & 00158 & 0.251873 & 0.00394 & 007603 & 0.000827 & 613383 & 00618 & 5.98866 & 0.056766 & 0.845048 & 0.0053332 & 0017004 & .000324 & 0.02308 & 0.0005 & 0.90766 & 0.00611 \\
\hline RL09-4.1 & $1.00 \mathrm{E}-32$ & $1.00 \mathrm{E}-32$ & 1218357 & 00073 & 0.032991 & 0.00063 & 0.35871 & 0.002362 & 0.602482 & 0.00286 & 5.91297 & 0.027262 & 0.103178 & 0.0005569 & & .000159 & 0.1095 & 0.001 & & 0.00068 \\
\hline RL09-5.1 & $2,13328 \mathrm{E}-21$ & $2.02 \mathrm{E}-13$ & 0.1182321 & 0.00165 & 0.299866 & 0.00466 & 0.06291 & 0.000748 & 0.652327 & 0.00721 & 6.22194 & 0.064747 & 0.98082 & 0.0065396 & 001659 & 0.000346 & 0.01869 & 0.0004 & 6093 & 007482 \\
\hline 250961 & 3,22865E-05 & 7.41E-06 & 0.1225999 & 0.0005 & 0.061661 & 0.0006 & 0.77714 & 0.004332 & 0.570435 & 0.00187 & 6.12837 & 0.020184 & 0.204893 & 0.0006318 & 0015056 & 0.000104 & 0.23046 & 0.0015 & & \\
\hline 09-8 1 & $1.00 \mathrm{E}-32$ & $1.00 \mathrm{E}-32$ & 1206978 & .00067 & 0.436023 & 0.00235 & 0.47012 & 0.003062 & 0.598165 & 0.00264 & 5.95413 & 0.02576 & 1.322084 & 0.0039149 & 0016471 & 0.000146 & 0.14228 & 0.0012 & 1.41846 & 0.004410 \\
\hline RI 0901 & $J,+500+\mathrm{T}-0 \mathrm{~J}$ & $1.98 \mathrm{E}-05$ & 0.1236768 & 0.0013 & 0.200101 & 0.00286 & 0.1167 & & 0.592844 & 0.00487 & 5.79993 & 0.045002 & 0.677527 & & & & 0.03628 & 0.0006 & & $2004252^{2}$ \\
\hline RL09-10.1 & 0,006761704 & 0.001478 & 0.1646282 & 0.00813 & 0.347387 & 0.02028 & -767.22 & 572.0044 & 0.456015 & 0.01789 & 7.48547 & 0.257092 & 0.208873 & 0.0061062 & 0.008452 & 0.000563 & -208.998 & 15.059 & 0.23509 & 0.007722 \\
\hline L09-11.1 & $3,59565 \mathrm{E}-05$ & $2.08 \mathrm{E}-05$ & 0.1207067 & 0.00132 & 0.34521 & 0.00398 & 0.11225 & 0.001074 & 0.605811 & 0.00514 & 6.04373 & 0.048256 & 1.126898 & 0.0057987 & 0.016394 & 0.000264 & 0.0342 & 0.0006 & 1.21291 & 0.00658 \\
\hline
\end{tabular}

